Est $\mathrm{Ag} 45$ (2008) 15-57

\title{
Dios como "sujeto" de la teología: su relevancia en una cultura postcristiana y postsecular
}

\author{
$\dagger$ In memoriam \\ S.E. Mons. Eugenio Romero Pose
}

\section{Planteamiento: Teología hoy}

En este ciclo de conferencias con ocasión del XL aniversario de nuestra Facultad de Teología del Norte de España, en su doble sede de Burgos y de Vitoria, me corresponde intervenir sobre un tema cuyo título suena así: "Dios como 'sujeto' de la teología: su relevancia en una cultura postcristiana y postsecular"1. Con esta contribución a la efemérides que conmemoramos quiero ante todo rendir un homenaje agradecido a los profesores que han hecho posible el recorrido de estos cuarenta años, bastantes de los cuales ya no están entre nosotros².

\footnotetext{
1 Ofrecemos aquí una reelaboración ampliada en su extensión y enriquecida con notas de la conferencia tenida en Burgos el día 16.04.2008 y en Vitoria el día 17.04.2008, así como de la intervención tenida en el Estudio Teológico Agustiniano de Valladolid el 23.5.08; una síntesis de las intervenciones ha sido publicada bajo el título de Tarea y relevancia de la teología en la situación presente en "Burgense" 49 (2008) 121-125.

2 Recuerdo a los distintos profesores de la Facultad de Teología en sus dos sedes, que nos han dejado en los últimos años: Ambrosio Rebollo, Nicolás López, Féliz Rodríguez, Juan de Sahagún Lucas, Andrés Ibánez, José María Ochoa, Féliz Ortiz de Urtaran, Ignacio Oñatibia. Por razones de cercanía personal quiero dedicar este trabajo a S. E. Mons. D. EUGENIO ROMERO POSE, quien fallecía hace apenas un año, el 23 de marzo de 2007. Con él me unían vínculos de una larga amistad, trabada en nuestros años de doctorandos en la Universidad Gregoriana de Roma, en las estancias conjuntas por tierras alemanas, en el desempeño de obligaciones docentes y académicas, en la colaboración sincera con las distintas responsabilidades que a él le correspondieron en el seno de la Conferencia Episcopal Española.
} 
Que yo, en cuanto teólogo y, en este caso, Decano de una Facultad de Teología, hable de Dios constituye una obviedad: ¿de qué podría y debería hablar, si no es de Dios? ¿cómo pretender decir algo sobre otras cosas en cuanto teólogo, si no es desde su relación con Dios? ¿qué sentido tendría en último término una Facultad de Teología que, en la multiplicidad de sus actividades, relegara esta cuestión central ? $^{3}$

Pero, si esto es obvio para mí, no lo es menos que en determinados contextos culturales la misma existencia de Facultades de Teología constituye hoy un hecho debatido. No sólo en países en los que quedaron excluídas de los ámbitos universitarios estatales, como es el nuestro, y en los que a veces se plantea la pregunta por la posibilidad o imposibilidad de su retorno; sino también en aquellos donde siguen formando parte de la Universidad desde sus mismos orígenes y lo que se discute hoy es la configuración y especificidad de su presencia ${ }^{4}$. Nada extraño, pues, que la pregunta por el quehacer de la teología cristiana, con sus peculiaridades confesionales 5 , en una Europa marcada también por la presencia de otras religiones (judaísmo, islam, budismo, hinduismo), por el hecho de la increencia religiosa y por transformaciones culturales muy rápidas, constituya un tema obligado para la reflexión teológica ${ }^{6}$.

A él me vinculaba igualmente el interés común por muchas cuestiones teológicas y el haber compartido juntos tareas docentes en la sede de Burgos de nuestra Facultad de Teología, donde él asumió diversos empeños en el ciclo institucional y en los cursos de licenciatura de 1978 a 1987. Es lógico, por tanto, que mi recuerdo y agradecimiento lo exprese no sólo a título personal, sino también en cuanto Decano de la sede de Burgos. Para su bio-bibliografía y su producción teológica, cf. los dos vols. ed. por J. J. Calvo Ayán, E. ROMERO POSE, Scripta Collecta, I: Estudios sobre el Donatismo, Ticonio y Beato de Liébana, II: La siembra de los Padres, Madrid 2008. No me ha sido posible, por distintos motivos, colaborar en el homenaje coordinado por S. PÉREZ LóPEZ (coord.), Plenitudo veritatis. Homenaje a Mons. Romero Pose, Santiago de Compostela 2008; con la dedicación de este trabajo me uno a los homenajes merecidos que ha recibido.

3 En parte retomo y prolongo aquí algunas reflexiones incluidas en mi lección inaugural del curso 2001-2002, S. DEL CURA ELENA, A tiempo y a destiempo. Elogio del Dios (in)tempestivo, "Burgense" 43 (2002) 323-378, así como en ID., Retos y signos de esperanza para la Iglesia en Europa: la contribución de la teología, en Fe cristiana y futuro: fundamentos y horizontes de la cultura europea, V Jornadas de Teología, Santiago de Compostela 2005, 127-188.

${ }^{4}$ Cf., H. HOPING (ed.), Universität ohne Gott? Theologie im Haus der Wissenschaften, Freiburg i.B. 2007.

5 Cf., entre otros, O. H. PESCH - J.M. VAN CANGH (dir.), Comment faire de la théologie aujourd'hui? Continuité et renouveau, Académie Internationale des Sciences Religieuses, Bruxelles - Louvain 2003; M. E. BRINKMANN e.a. (eds.), Theology between Church, University, and Society, Assen 2003; A. GERHARDS (ed.), Übersetzen. Bibel, Spiritualität und Glaubensästhetik. Zur Aufgabenstellung der Theologie in den säkularisierten Gesellschaften Frankreichs und Deutschlands, Münster 2004.

6 Cf. las distintas colaboraciones incluidas en P. HÜNERMANN - J. SCHMIED (ed.), Der Weg Europas und die öffentliche Aufgabe der Theologien, Berlin 2007. 
La situación tiene que ver, sin duda, con el proceso de secularización de la época moderna, con las características peculiares del discurso teológico cristiano ${ }^{7}$ y con la dimensión pública de la fe cristiana ${ }^{8}$, temas complejos en sus múltipes implicaciones. Pero la exclusión o modificación del statu quo de las Facultades de Teología no significa, sin embargo, que la teología en cuanto tal sea imposible. Su presencia en nuestras Universidades españolas resultaría, a mi modo de ver, benéfica para la misma teología (obligada así a una mayor exigencia de rigor y a un diálogo permanente con otras formas de pensar) y también para el resto de los saberes (no menos necesitados de superar a veces enclaustramientos metodológicos o absolutizaciones ideológicas) ${ }^{9}$.

En cualquier caso, la teología se cultiva hoy dentro y fuera de los ámbitos universitarios y se seguirá cultivando, más allá de la posible ampliación o modificación de su presencia en el curriculum académico de los estudios superiores. Su vitalidad no depende sólo ni primordialmente de su integración en las estructuras del sistema universitario vigente, por importante que éste sea. En la vitalidad de la teología juegan un papel determinante también otros factores decisivos. Especialmente el modo en que sepa abordar y presentar la pregunta por Dios: aquí tiene la teología su tema permanente, su norte de referencia y su capacidad potencial para provocar interrogantes y suscitar interés. Pues no en vano la cuestión afecta a muchos millones de seres humanos que se profesan creyentes; pero transciende al mismo tiempo estos ámbitos por estar llena de resonancias antropológicas, sociales, filosóficas y culturales.

Por otro lado, en torno al sentido de la teología se producen debates también en el interior del cristianismo y en los ámbitos intraeclesiales. Una mirada a la historia ${ }^{10}$ bastaría para corroborar las distintas formas de

7 Cf., I. U. DALFERTH, Jenseits von Mythos und Logos. Die christologische Transformation der Theologie, Freiburg i.B. 1993.

8 Cf., E. ARENS - H. HOPING (ed.), Wieviel Theologie verträgt die Öffentlichkeit?, Freiburg i.B. 2000.

9 Un ejemplo de diálogo interdisciplinar en torno al discurso de Benedicto XVI en Ratisbona ha sido ofrecido por la misma Universidad donde tuvo lugar, cf. C. DOHMEN (ed.), Die "Regensburger Vorlesung" Papst Benedikts XVI. im Dialog der Wissenschaften, Regensburg 2007. Cf., valoraciones ulteriores en K. WENZEL (ed.), Die Religionen und die Vernunft. Die Debatte um die Regensburger Vorlesung des Papstes, Freiburg i.B. 2007 y en las distintas colaboraciones incluidas en Dio salvi la ragione, Siena 2007.

10 Cf.: el art. "Theologie" en Catholicisme 14 (1996) 1009-1099 y el art. "Theologie" en RGG 8 (2005) 263-306; para nuestra época, cf. G. CANOBBIO - P. CODA (eds.), La Teologia del XX secolo, un bilancio, 3 vols., Roma 2003. 
entender el quehacer teológico, los acentos más racionales o más sapienciales, los diversos interlocutores del diálogo y los destinatarios de su reflexión, las relaciones complejas entre fe popular y discurso teológico científico, la importancia de los condicionamientos sociopolíticos y de las corrientes culturales, las relaciones entre racionalidad creyente y otras formas de racionalidad, la difícil conciliación entre la urgencia de soluciones pastorales y la importancia de los problemas de fondo. No siempre el debate teológico se produce por propuestas críticas con instancias magisteriales o con ciertas formas de comportamiento eclesial. Los motivos son mucho más amplios y diversificados. Y lo que en conjunto plantean es el sentido mismo del quehacer teológico ${ }^{11}$ en su relación con la fe, con el existir creyente, con la vida de las comunidades cristianas, con las culturas y las racionalidades respectivas de las diversas épocas, con los distintos lugares o los diversos contextos en que se articula la reflexión creyente ${ }^{12}$.

En resumen, la teología se ve obligada a legitimarse hoy como tal, en sus pretensiones y en su razón de ser, no sólo en ámbitos universitarios, estatales y no estatales, sino también en muchos otros ámbitos de la vida cristiana y en las circunstancias cambiantes de la sociedad contemporánea13. Sería ingenuo y presuntuoso por mi parte tratar aquí toda esta problemática ad intra y ad extra. Por ello me limitaré a exponer y justificar una convicción: difícilmente podrá la teología llevar a cabo dicha tarea de legitimación sin hacer valer ante todo su pretensión de hablar de Dios, tarea que define a la TeOlogía en su sentido más estricto ${ }^{14}$. Así ha sido en el pasado y no puede ser muy distinto en el presente, si bien éste conoce situaciones nuevas y cambios profundos respecto a otros momentos históricos. En mi exposición explicaré brevemente por qué hablo de Dios como "sujeto" de la teología (1), a continuación comentaré el diagnóstico de la cultura actual como "postcristiana" y "postsecular" (2), dedicando

11 Cf., J. RATZINGER, Theologische Prinzipienlehre. Bausteine zur Fundamentaltheologie, München 1982; ID., Natura e compito della teologia, Milano 1993; O. GONZÁLEZ DE CARDEDAL, El quehacer de la teología. Génesis, estructura, misión, Salamanca 2008.

12 Cf., K. KRETUZER e.a. (eds.), Gefährdung oder Verheissung? Von Gott reden unter den Bedingungen der Moderne, Mainz 2007; P. HARDT - K. VON STOSCH (eds.), Für eine schwache Vernunft? Beiträge zu einer Theologie nach der Postmoderne, Mainz 2007.

13 Cf., C. SEDMAK, Theologie in nachtheologischer Zeit, Mainz 2003; los diversos trabajos reunidos en ID., (ed.), Was ist gute Theologie?, Innsbruck 2003; P. CODA, Teologia. La Parola di Dio nelle parole umane, Roma 2004; E. GRAHAM e.a., Theological Reflection: Methods, London 2005.

14 Cf, R. A. SIEBENROCK, Gott - das Thema der Theologie. Eine exemplarische Orientierung zum Diskussionsstand der deutschprachigen Theologie, ZKTh 130 (2008) 334-345. 
una tercera parte a algunos puntos de más relieve donde percibir el alcance de Dios como "sujeto" de la teología en la situación presente (3).

\section{La tesis: Dios como "sujeto" de la teología}

En el quehacer teológico nos encontramos con una situación peculiar: Dios, que es el "objeto" de la teo-logía15, es decir, el tema sobre el que versa su lenguaje y su discurso, es y ha de seguir siendo el "sujeto" de la teología ${ }^{16}$, es decir, su verdadero protagonista, para que la teología pueda retenerse en verdad habla de Dios (logos - theou) y no solamente un hablar sobre Dios. Así podría resumirse la tesis central que constituye el presupuesto de esta exposición, esperando poder ofrecer en otro momento un tratamiento más amplio y explícito de esta tesis.

Ahora bien, ¿por qué poner el acento sobre Dios como "sujeto" de la teología y cuál puede ser el alcance de esta tesis? La respuesta es obvia: porque así será más fácil que Dios, su palabra y su realidad, resulten transparentes en las mediaciones de los teólogos y que Dios goce, en el quehacer teológico, de la misma primacía que le es reconocida en la fe y que ha de resultar perceptible en el conjunto de las acciones eclesiales.

Esta primacía se hallaba ya incluida en la expresión técnica, apenas mencionada, de Sto. Tomás de Aquino, cuando afirmaba que Dios es el "sujeto" de la teología. Pero pocas citas podrían ilustrar mejor su sentido que las palabras que el papa Benedicto XVI nos dirigía a los miembros de la Comisión Teológica Internacional en la reunión del 6 de octubre de 2006: "Santo Tomás de Aquino, aseguraba el papa, dice que en la teología Dios no es el objeto del cual hablamos. Ésta es nuestra concepción nor-

15 La insistencia de W. PANNENBERG, Grundfragen systematischer Theologie, I, Göttingen 1988, 14s en que Dios mismo es el "objeto" (Gegenstand) de la teología quiere resaltar la misma precedencia de Dios que la tesis sobre su condición en cuanto "sujeto"; lo cual corrobora que la cuestión de las palabras es en este caso más bien secundaria.

16 Ya decía Sto. Tomás: "Omnia autem pertractantur in sacra doctrina sub ratione Dei: vel quia sunt ipse Deus; vel quia habent ordinem ad Deum, ut ad principium et finem. Unde sequitur quod Deus vere sit subiectum huius scientiae", STh I q1 a7; en el mismo texto, no obstante, los términos "sujeto" y "objeto" son correlativos: "sic enim se habet subiectum ad scientiam, sicut obiectum ad potentiam vel habitum", ib. q1 a7 c (subrayados míos). Sobre el alcance de la condición de Dios como "sujeto" de la teología en Sto. Tomás, cf. J. P. TORRELL, La théologie catholique, Paris 2008 ( $2^{\mathrm{a}}$ ed. con un Postscriptum de 2008)) 64-66; un tratamiento más amplio en ID., Initiation à saint Thomas d'Aquin. Sa personne et son oeuvre, ParisFribourg 2002 ( $2^{\mathrm{a}}$ ed.). 
mal. Pero en realidad, Dios no es el objeto: Dios es el sujeto de la teología. Quien habla en la teología, el sujeto hablante, debería ser Dios mismo. Y nuestro hablar y pensar debería servir únicamente para que el hablar de Dios y la Palabra de Dios puedan ser escuchadas y puedan encontrar espacio en el mundo. Así nos encontramos invitados a un camino de purificación, para que nuestras palabras sean sólo instrumento mediante el cual Dios pueda hablar, y así Dios sea realmente no objeto, sino sujeto de la teología"17.

El quehacer teológico se encuentra de este modo ante una responsabilidad difícil ${ }^{18}$ y exigente: hacer valer a Dios como el verdadero "sujeto" de la teología. ¿Cómo proceder para que así sea? La teología utiliza una gran variedad de recursos, caminos y mediaciones en sus diversas tareas y materias $^{19}$. Pues, bien, todo ello deberá favorecer la transparencia de Dios a través de los procedimientos metodológicos, nunca convertir éstos en un posible obstáculo para su percepción. Cuando hoy día se desea una teología más "teológica"20, por redundante que suene la expresión, estamos ante un deseo que tiene su razón de ser y que encaja en el acento puesto en Dios como "sujeto" de la teología. Con ello no se olvida para nada que Dios es tal "por nosotros y por nuestra salvación", ni se ignora el componente antropológico de toda teología, ni se cuestiona la necesidad de que el quehacer teológico se ejerza a favor de los hombres. Sencillamente se recuerda que, en el discurso reflexivo de la racionalidad creyente, el verdadero protagonista ha de ser Dios, al que la teología escucha de modo obediente ( $o b$ audire) y al que continuamente ha de remitirnos como cometido suyo.

No podrá tratar a Dios, por tanto, como un "objeto" más de los que aborda, ni podrá hablar de Dios como si fuera una realidad "objetual" entre otras. Que Dios sea "sujeto" de la teología significa que Dios tiene la precedencia absoluta y que las palabras articuladas por nosotros han de servir a esta primacía. En fin de cuentas, es con la realidad de Dios con la que en último término hemos de sentirnos confrontados en todas las

17 Homilía durante la Misa con los miembros de la CTI, 6, octubre, 2006.

18 Cf., C. DUQUOC, La teologia in esilio. La sfida della sua sopravvivenza nella cultura contemporanea, Brescia 2004 (orig. francés 2002), donde el autor describe las características de una coyuntura inhóspita para la teología en cuanto tal, valora las diversas reacciones de rigidez y de apertura y propone una posible vía de salida, caracterizada por la prioridad del debate, la modestia en las propuestas y en las afirmaciones y la renuncia a pretensiones sistemáticas, absolutas o definitivas.

19 Cf., M. SodI (ed.), Il metodo teologico. Tradizione, innovazione, comunione in Cristo, Città del Vaticano 2008.

20 Cf., W. KASPER, El Dios de Jesucristo, Salamanca 1985, 357. 
mediaciones teológicas posibles. $\mathrm{Y}$ es este criterio de referencia lo que ubica a la teología en su lugar adecuado y lo que relativiza sanamente sus posibles pretensiones desmedidas.

No tanto un método teológico o una praxis concreta, cuanto Dios mismo como "sujeto" de la teología es quien le otorga su unidad más honda. Pero, para hacer posible que resuene la misma voz de Dios en las palabras humanas de la teología, ésta también ha de hablar del mundo y del hombre, de su creación y de su salvación, del fundamento de su existencia y de la plenitud de su destino. Así podrán percibir los destinatarios la voz de Dios revelado en el acontecimiento Jesucristo. En la historia protagonizada por él se ha manifestado Dios como el amigo de los hombres, en su rostro ha brillado la compasión de Dios Padre, en su vida se ha dado la actuación suprema del Espíritu Santo que abre a todos los hombres el horizonte de una nueva comunión con Dios. El Dios de Jesucristo es el Dios trinitario, Padre, Hijo y Espíritu Santo, el Dios que no solamente nos ama, sino que en sí mismo es amor (cf. 1Jn 4,8). Y pensar hasta el fondo desde este horizonte omniabarcante del amor divino la realidad entera, haciendo comprensible así la verdad de Dios, constituye para la teología un desafío poderoso que bien vale la pena afrontar. Es el camino para hacer valer simultáneamente su identidad y su relevancia también hoy día. No sin motivos el misterio de Dios constituye el tema teológico por antonomasia 21 .

Al hilo, no obstante, de la tesis aquí asumida como presupuesto, surgen al menos dos preguntas inmediatas: ¿cómo hacer para que realmente Dios hable a través de las mediaciones teológicas como su verdadero "sujeto", si la teología es un quehacer humano elaborado trabajosamente y en ella la revelación de Dios es presentada por hombres a los hombres bajo las condiciones antropológicas inherentes a cualquier tipo de conoci-

$21 \mathrm{Cf}$, entre los muchos autores recientes que podrían citarse, sólo algunos ejemplos: $\mathrm{O}$. GONZALEZ DE CARDEDAL, Dios, Salamanca 2004; L. F. LADARIA, El Dios vivo y verdadero, Salamanca 1998; ID. La Trinidad, misterio de comunión, Salamanca 2002; J.M. ROVIRA BELloso, Dios: Padre, Hijo y Espíritu Santo, Salamanca 2008; A. K. MIN, Paths to the Triune God. An Encounter between Aquinas and Recent Theologies, Notre Dame, Indiana 2005; M. VOLF - M. WELKER (eds.), God's Life in Trinity, Minneapolis 2006; K. MÜLLER, Streit um Gott. Politik, Poetik und Philosophie im Ringen um das wahre Gottesbild, Regensburg 2006; A. KREINER, Das wahre Antlitz Gottes - oder was wir meinen, wenn wir Gott sagen, Freiburg i.B. 2006; J. WERBICK, Gott verbindlich. Eine theologische Gotteslehre, Freiburg i.B. 2007; G. WENZ, Gott. Implizite Voraussetzungen christlicher Theologie, Göttingen 2007; H-G. WITZ (ed.), Dreieinig Einer. Das Ringen um das christliche Gottesbild: eine bleibende Herausforderung, Mainz 2008; W. KASPER, Der Gott Jesucristi (Vorwort zur Neuausgabe), Freiburf i.B 2008; G. COTTIER, Le désir de Dieu, Paris 2002; J. MOINGT, Dieu qui vient à l'homme, 1: Du deuil au dévoilement de Dieu, Paris 2002; 2: De l'apparition à la naissance de Dieu, Paris 2005, 2007. 
miento, de lenguaje y de discurso 22 ? ¿qué valor otorgar a un esfuerzo de reflexión creyente, que resulta con frecuencia tan arduo y complejo y que en su verdadero alcance queda relativizado precisamente por su referencia primigenia a Dios como el "sujeto" de la teología?

Que las propuestas teológicas sean obra humana y no puedan equipararse sin más con la Palabra de Dios es un hecho que libra a la teología de presunciones equivocadas y le recuerda que está no por encima de la Palabra de Dios, sino a su servicio (cf. DV 8). Para hacer valer a Dios como "sujeto" de la teología será, por tanto, cuestión decisiva la relacionada con los procedimientos metodológicos seguidos; la pregunta por el método teológico no es un aspecto meramente formal, sino que es al mismo tiempo una pregunta por la especificidad de la teología y por sus contenidos. Y, en lo referente al valor del quehacer teológico, podemos recordar de nuevo la intervención de Benedicto XVI ya citada, en la cual, inspirándose en un suceso atribuido a Sto. Tomás de Aquino al final de sus días ${ }^{23}$, sostiene que el valor de la teología es semejante al de la "paja" en relación con el "grano"; lo cual no significa que la paja carezca de valor alguno: en ella se contiene el grano ${ }^{24}$. A mí me parece que, en esta perspectiva, la teología sigue teniendo pleno sentido también hoy.

A pesar de las dificultades innegables, que el ejercico de este quehacer conlleva precisamente en la situación actual. Entre los retos enumerados por Juan Pablo II en su Exhortación apostólica "Iglesia en Europa" (2003) se mencionaba la impresión de que en la cultura europea de hoy lo obvio es la increencia y lo necesitado de legitimación la fe, así como la apostasía silenciosa del hombre autosuficiente que vive como si Dios no

22 Sobre el componente humano de la teología en cuanto ciencia de la fe, cf. M. SECKLER, Theologie als Glaubenswissenschaft, en W. KERN (ed.), Handbuch der Fundamentaltheologie, 4, Freiburg i.B. 1988, 179-241.

23 Cf., J. P. TORRELL, o.c. supra n. 16.

24 En la homilía ya citada del 6.10.06 decía también Benedicto XVI: "Job había clamado a Dios, incluso había luchado con Dios frente a las evidentes injusticias con las que lo trataba. Ahora se encuentra ante la grandeza de Dios. Y comprende que ante la verdadera grandeza de Dios todo nuestro hablar es sólo pobreza y no llega, ni siquiera de lejos, a la grandeza de su ser; así dice: "He hablado dos veces y no añadiré nada". Silencio ante la grandeza de Dios, porque nuestras palabras son demasiado pequeñas. Esto me lleva a pensar en las últimas semanas de la vida de santo Tomás. En esas últimas semanas ya no escribió ni habló nada. Sus amigos le preguntaron: "Maestro, ¿por qué ya no hablas?, ¿por qué ya no escribes?". Y él respondió: "Ante lo que he visto ahora todas mis palabras me parecen como paja"... La paja no equivale a nada. La paja lleva el grano y este es el gran valor de la paja. Lleva el grano. Y también la paja de las palabras sigue siendo válida como portadora del grano. También para nosotros esto es una relativización de nuestro trabajo y a la vez una valorización de nuestro trabajo. Es asimismo una indicación para que nuestro modo de trabajar, nuestra paja, lleve realmente el grano de la palabra de Dios". 
existiera y el surgimiento de una nueva cultura en contraste con el evangelio $^{25}$. Ante tal desafío la teología, que es tanto fides quaerens intellectum como intellectus quaerens fidem, está obligada a confrontarse de nuevo y de manera renovada con la realidad de Dios, revelada en el acontecimiento Jesucristo.

En este cometido el discurso teológico de hoy no puede limitarse sólo a precisar los contenidos de la fe cristiana en Dios, sino que ha de inscribir entre sus preocupaciones también la pregunta por la fundamentación, la comunicabilidad y la transmisión de los mismos. No es, ciertamente, uniforme el panorama de las propuestas actuales a propósito de la racionalidad teológica; incluso hay corrientes en las cuales se sostiene que a la teología no se la ha perdido nada en el juego de ofrecer y de exigir razones que fundamenten la fe. A mí me parece, sin embargo, que también hoy la teología ha de buscar la mediación entre creer y pensar, pues, aunque puedan variar los interlocutores, los caminos y los procedimientos a la hora de llevar a cabo la tarea, los creyentes y los teólogos siempre habremos de dar razón de nuestra fe.

Ésta es culto espiritual o "rationale obsequium" (logiké latreia, Rom 12,1), dispuesta a dar razón (apologia) de la esperanza que hay en nosotros (cf. 1Ped 3,15). Por ello, la teología conlleva necesariamente una responsabilidad racional-discursiva cuando aborda su tema más propio, la realidad de Dios; S. Agustín la definía como "ratio sive sermo de divinitate"26 y Sto. Tomás de Aquino aseguraba que la teología trata de Dios en primer lugar, y también de las cosas creadas en la medida de su relación con Dios como origen y como meta ${ }^{27}$. Hacer valer de nuevo la condición de Dios como "sujeto" de la teología constituye así para el quehacer teológico contemporáneo una necesidad, un estímulo y una oportunidad. También y especialmente en las circunstancias actuales.

\section{El contexto: una nueva situación cultural}

La situación actual se caracteriza por un pluralismo religioso y cosmovisivo, en el que se dan tendencias no sólo diversas, sino también de

25 Cf. Ecclesia in Europa (2003) $\mathrm{n}^{\circ} 7-17$.

${ }^{26}$ Cf., De civ. Dei, VIII, 1.

27 "Omnia autem pertractantur in sacra doctrina sub ratione Dei: vel quia sunt ipse Deus; vel quia habent ordinem ad Deum, ut ad principium et finem", STh I q1 a7. 
signo contrario. De ahí la paradoja que ofrece el diagnóstico presente a la luz de los diversos estudios sobre la fe en Dios y las creencias religiosas, circunscritos especialmente al ámbito occidental europeo.

Por un lado, la crisis religiosa parece alcanzar niveles de difusión y de radicalidad hasta ahora desconocidos, con incidencia especial en el Dios de la tradición cristiana, mayoritaria en el pasado y todavía en el presente de la historia europea; las distintas formas de ateísmo, agnosticismo e indiferencia religiosa corroboran la configuración de una cultura postreligiosa, que en Europa es sobre todo postcristiana. De otra parte, la capacidad de resistencia y adaptación demostrada por la fe cristiana, la penetración de tradiciones religiosas distintas del cristianismo, la crisis innegable de la modernidad ilustrada y la vigencia de diversas formas de religiosidad más o menos sincretista y difusa parecen cuestionar la tesis de una sociedad europea profundamente secularizada. A esta complejidad paradójica obedece la caracterización de la cultura actual como "postcristiana" y "postsecular" al mismo tiempo 28.

No es fácil discernir si estamos ante tendencias contradictorias o si hay más bien entre ellas una correlación de fondo no perceptible a primera vista. En cualquier caso, la teología ha de tomar nota de este diagnóstico paradójico, proporcionado por los estudios sociológicos y las interpretaciones culturales del momento actual, para identificar los verdaderos desafíos del discurso cristiano sobre Dios, descubrir signos de esperanza en medio de la paradoja presente y transformar las dificultades reales en oportunidades nuevas para el Dios revelado en Jesucristo ${ }^{29}$.

\subsection{Una cultura "postcristiana"}

Parte de la cultura actual, no toda ni en su conjunto si se tiene en cuenta el número de creyentes y el hecho real de una cultura radicada en

\footnotetext{
28 Se ha de reconocer la omnipresencia del prefijo "post" en el lenguaje actual, con contenidos diversos en función de la realidad a la que se aplica: así se habla de "postmodernidad" como se habla de "posthistoria" (F.Fukuyama), de sociedad "postindustrial" (A. Touraine), de época "postliberal" (G. Lindbeck), de "postmetafísica" (J. Habermas), o de era "postcristiana" (E. Poulat); cf. S. DEL CURA ELENA, El hombre ante el Misterio de Dios: Teo-logía y postmodernidad, en A. GALINDO GARCIA - J.M. SÄNCHEZ CARO (eds.), El hombre ante Dios. Entre la hipótesis y la certeza, Salamanca 2003, 17-55.

${ }^{29}$ Cf., S. DEL CURA ElENA, Realidad de Dios y propuestas pastorales: "Etsi Deus (non) daretur", en M.A. PENA - J.R. FLECHA - A. GALINDO (eds.), Gozo y esperanza, Memorial Prof. J. A. Ramos Guerreira, Salamanca 2006, 245-274.
} 
presupuestos cristianos, puede ser calificada, no obstante, de "postreligiosa"; más en concreto, de "postcristiana", término preferido aquí por circunscribirnos al ámbito occidental europeo.

El término "postcristiano" incluye un doble significado: una posterioridad cronológica, aneja en este caso a la convicción de que el cristianismo pertenecería ya a épocas pasadas y habría perdido capacidad para configurar las decisiones existenciales del hombre contemporáneo; pero también una posterioridad crítica, pues se articula en reacción adversa frente al cristianismo, del que intenta llevar a cabo un proceso de desenmascaramiento y deconstrucción ${ }^{30}$. El desarrollo constituye en sí un hecho nuevo no sólo respecto a la fe cristiana, sino también respecto a la fe en Dios propia de cualquier tradición religiosa: no consta en la historia anterior una presencia tan difusa y aparentemente aproblemática de actitudes increyentes. Es además un hecho llamativo, pues donde parece haber alcanzado más difusión es precisamente donde la fe cristiana en Dios adquirió mayor arraigo en la historia ${ }^{31}$, es decir, en Europa. Es finalmente una tendencia que, en opinión de bastantes sociólogos, no parece disminuir; tanto que, en la diversidad de términos acuñados como recurso expresivo de la relación entre cristianismo o catolicismo y cultura contemporánea (inculturación, aculturación), se ha propuesto también el de "exculturación" para caracterizar la situación del cristianismo y del catolicismo en algunos países europeos ${ }^{32}$.

Debido precisamente a esta situación, J.B. Metz afirmaba hace algunos años que, si la analizamos a fondo, la crisis presente no es sólo una crisis de iglesia(s), sino una crisis de Dios ("Gotteskrise"33). El diagnóstico es

\footnotetext{
30 Cf., K.H. WEGER (ed.), Religionskritik. Beiträge zur atheistischen Religionskritik der Gegenwart, München 1976; M.J. BUCKLEY, At the Origins of Modern Atheism, New Haven 1987.

31 Cf., A. CHARron, Les catholiques face à l'athéisme contemporain, Montreal 1973; J. FIGL, Atheismus als theologisches Problem, Mainz 1977; S. DEL CURA ELENA, Ateísmo e increencia como tema de la teología. Algunas características de su desarrollo en España, "Salmanticensis" 35 (1988) 201-241.

32 Cf., D. HervieU-Leger, Catholicisme, la fin d'un monde, Paris 2003, quien acuña el término de "exculturación" para describir el proceso de "descatolización" acontecido en el ámbito francés (cf. pp. 91-132).

33 Cf., J.B. METZ, Gotteskrise, en ID. u.a., Diagnosen zur Zeit, Düsseldorf 1994, 76-92; ID., Gotteskrise als Signatur der Zeit, en J. HUBER - A.M. MÜLLER (ed.), Instanzen, Perspektiven, Imaginationen, Basel-Frankfurt a.M. 1995, 95-110; ID., Kirche in der Gotteskrise, en Sind die Kirchen am Ende?, Regensburg 1995, 158-175; ID., Im Eingedenken fremden Leids. Zu einer Basiskategorie christlicher Gottesrede, en ID. u.a., Gottesrede, Münster 1996, 3-20; ID., Gotteskrise - Kirchenkrise, en P. REIFENBERG u.a. (ed.), Licht aus dem Ursprung, Würzburg
} 
compartido por tendencias teológicas distintas. Así, en el congreso celebrado con ocasión del setenta cumpleaños de Metz, decía el entonces cardenal J. Ratzinger que sólo desde esta radicalidad pueden esclarecerse las demás crisis y puede buscarse a su vez una respuesta; otros autores retienen que algunos desarrollos intraeclesiales e intrateológicos durante la época postconciliar han podido alentar involuntariamente la tendencia, al centrar el interés de los debates en las instituciones eclesiales y relegar de hecho a un segundo plano la cuestión de Dios ${ }^{34}$.

Y se ha de reconocer que las crisis originadas por cuestiones relativas a las iglesia(s) en su realidad institucional están ahí y no pueden minimizarse. Pero la expresión acuñada por Metz quiere decir que las crisis eclesiales tienen las raíces más hondas, que solamente desde esta profundidad pueden esclarecerse, que la cuestión de Dios constituye el núcleo central y que desde aquí habrá de buscarse un camino de salida. La crisis, además, tiene una clara dimension ecuménica, más allá de las divergencias confesionales, puesto que a todos los creyentes afecta, a todos preocupa y, en este sentido, también a todos une.

Una manifestación de esta crisis radical en cuanto posterioridad cronológica se halla en la sensación difusa de que el tiempo de Dios hubiera pasado. Al menos en un sector influyente del pensamiento y de la cultura occidentales se piensa estar al final de una época, en el epílogo de una historia cuyo recuerdo se difumina progresivamente. Dios, así piensan algu-

Gotteskrise - Kirchenkrise, en P. REIFENBERG u.a. (ed.), Licht aus dem Ursprung, Würzburg 1998, 201-214; ID., Memoria passionis. Ein provozierendes Gedächtnis in pluraler Gesellschaft, Freiburg i.B. 2006. Para una valoración crítica de la toma de postura por parte de Metz, como síntoma de una inseguridad de la teología ante las diferencias necesarias en relación con la pregunta por el "tiempo", cf. H.J. SANDER, Sympton 'Gotteskrise'. Die Zeitsignatur der Theologie, ZKTh 121 (1999) 45-61. Para el conjunto de su pensamiento, cf. T.R. PETERS, J.B. Metz. Theologie des vermissten Gottes, Mainz 1998.

34 En el congreso celebrado con ocasión del setenta cumpleaños de Metz, decía el entonces cardenal J. Ratzinger: "Sie (Metz) haben ein grosses Stichwort ausgegeben mit dem Wort 'Gotteskrise' - ob es nun besonders glücklich formuliert ist oder nicht, darüber muss man nicht streiten... dass das Gottes-Thema in seiner ganzen Grösse, in seinem Anspruch, in seiner Herausforderung, in seiner Not die Mitte ist, dass alle anderen Krisen sich letzlich nur von daher erklären, und dass wir - wenn überhaupt - nur Antwort finden können, wenn wir an diesem Punkt neu ansetzen...", en T.R. PETERS - C. URBAN (ed.), Ende der Zeit? Die Provokation der Rede von Gott, Mainz 1999, 50 (trad. esp., J.B. METZ - J. RATZINGER e.a., La provocación del discurso sobre Dios, Madrid 2001). Para una exposición más amplia sobre la cuestión de Dios hoy, cf. su libro entrevista, J.K. RATZINGER, Gott und die Welt. Glauben und Leben in unserer Zeit. Ein Gespräch mit P. Seewald, Stuttgart-München 2000 (hay trad. española). Un diagnóstico semejante al de Metz puede leerse también en el libro de J.A. ESTRADA, Razones y sinrazones de la creencia religiosa, Madrid 2001,214s. 
nos, habría tenido en el pasado su momento y su esplendor; pero, de cara al futuro, su tiempo parecería haberse agotado. Sería el suyo un caso a punto de archivarse "sine die".

Las antiguas sospechas, acusaciones o críticas ejercen ahora su influjo en una nueva constelación, donde se quiere acentuar la irrelevancia cultural y pública de la pregunta por Dios, se la confina en el puro ámbito de la subjetividad privada, se la envuelve en un manto mortal de silencio, se evita el diálogo directo con las afirmaciones teológicas o se busca una apropiación selectiva de lo religioso, vaciándolo de su substancia originaria ${ }^{35}$. Como si no hubiera otra alternativa que la de asumir pacífica y razonablemente en los proyectos vitales las consecuencias de un desenmascaramiento que se da por concluido.

De ahí que la indiferencia religiosa de muchos aparezca como la actitud práctica más acorde con una despedida real, aunque a veces silenciosa, de toda cosmovisión creyente. O que crezca la "extrañeza" ante el Dios de la revelación cristiana, hasta no hace mucho connatural en las familias, en los ámbitos educativos o en las cosmovisiones culturales ${ }^{36}$. Extrañeza que afecta no sólo a imágenes más o menos circunstanciales o a simples tradiciones culturales arraigadas en la sociedad, sino también a los contenidos nucleares de la fe cristiana: el Dios hecho carne en Jesús de Nazaret, que resucita a los muertos, que se revela como Padre, Hijo y Espíritu Santo, que llama al hombre a participar de su misma vida.

Pero la dimensión de posterioridad cronológica, que tiende a retener la cosmovisión cristiana como un momento epocal de la historia europea perteneciente al pasado, se transforma también en posterioridad crítica del cristianismo. Baste aducir algunas referencias actuales como ilustración de esta tendencia "postcristiana". En diversas publicaciones relacionadas con el jubileo del año 2000 se ha llevado a cabo un balance crítico de los dos mil años de cristianismo, no sólo en el sentido de una "historia

35 Cf., D. LANGE, Die Rede von Gott angesichts moderner Religionskritik, ThRd 58 (1993) 310-332; K.H. NEUFELD, Kritik am Christentum, ZKTh 120 (1998) 402-412.

36 Cf., P. HÜNERMANN (ed.), Gott - ein Fremder in unserem Haus? Die Zukunft des Glaubens in Europa, Freiburg 1996; N. LASH, Among Strangers and Friends. Thinking of God in Our Current Confusion, en M.J. HIMES - St. J. POPE (ed.), Finding Gott in All Things, New York 1996, 53-67; Th. FAULHABER - B. STILlFRIED (ed.), Wenn Gott verloren geht. Die Zukunft des Glaubens in der säkularisierten Gesellschaft, Freiburg 1998. Lo que en el libro ed. por Hünermann aparecía bajo signo de interrogación aparece en sentido afirmativo en la reciente obra de L. DUCH, Un extraño en nuestra casa, Barcelona 2007. 
criminal" de sus actuaciones, sino llegando a proponer que la única petición de perdón aceptable sería su autodisolución ${ }^{37}$. A ello puede añadirse un conjunto de obras manifiestamente anticristianas o el aparente éxito editorial de obras como la "ateología" de M. Onfray38. El ateísmo a buen precio que en esa obra se ofrece constituye un reciclaje arbitrario de las críticas religiosas más habituales, animado por pretensiones perentorias tan desmesuradas como indemostrables, proclive a la denigración sistemática, carente de discusión argumentada y con enormes lagunas en materia de conocimientos religiosos; un ateísmo superficial, que jamás toma en serio a los creyentes ni reconoce riqueza alguna a los textos de las tradiciones religiosas 39 .

Igualmente, primero en el ámbito anglosajón y con prolongaciones posteriores en otros lugares, se ha ido articulando como un renacimiento de las críticas ateas que es calificado por algunos como "nuevo(s) ateísmo(s)" 40 . No todo puede reducirse a común denominador ni tampoco es idéntico el nivel de la discusión; junto a obras llenas de tópicos ateos comunes, sin originalidad ni rigor argumentativo, hay propuestas que bien merecen atención y debate por parte de la teología 41 . No obstante, con frecuencia se mantiene de forma agresiva que las personas religiosas son en el fondo unos pobres infelices, cuando no personalidades necias o amorales; se predica una imagen del mundo puramente "científica", donde todas las ideas religiosas quedan supuestamente desautorizadas por una interpretación exclusivamente biologicista - naturalista del ser humano; las profesiones de fe monoteísta, incluída la cristiana, son equiparadas sin mayores matices con fuentes de intolerancia, inmoralidad, fanatismo y violencia.

37 Cf., R. RÉMOND, Le christianisme en accusation. Entretiens avec M. Leboucher, Paris 2000; F.X. KAUFMANN, Wie überlebt das Christentum?, Freiburg i.B. 2000; U. RUH, Umstrittenes Christentum. Neuerscheinungen zu einem weithin vernachlässigen Thema, HK 55 (2001) 67-71.

38 Cf., M. ONFRAY, Traité d' athéologie. Physique de la métaphysique, Paris 2005.

39 Cf., para una confrontación crítica con la obra de M. Onfray, M. BAUMIER, L'anti traité d'athéologie. Le systéme Onfray mis à nu, Paris 2005; R. REMOND, Vers un nouvel antichristianisme? Entretiens avec Marc Lebouche, Paris 2005; M. FOESSEL, L'athéisme dérisoire de M. Onfray, "Esprit" 314 (2005) 75-86; E. BRITO, L'athéologie sans peine, de M. Onfray. À propos d'un livre récent, RThL 37 (2006) 79-85.

40 Cf. T. BEATTIE, The New Atheists. The Twilight of Reason and the War on Religion, London 2007; J. F. HAUGHT, God and the New Atheism. A Critical Response to Dawkins, Harris, and Hitchens, Louisville, Kentucky 2008; M. STRIET (ed.), Wiederkehr des Atheismus. Fluch oder Segen für die Theologie?, Freiburg i.B. 2008.

41 Cf., H. KESSLER, "Das Konzept Gott - warum wir es nicht brauchen" (B. Müller)? Auseinandersetzung mit einem respektablen Atheismus, en G. AUGUSTIN - K. KRÄMER (eds.), Gott denken und bezeugen, Freiburg i.B. 2008, 512-541; se refiere a B. MÜLLER, Das Konzept Gott - warum wir es nicht brauchen, "Merkur" 61 (2007) 93-102. 
A todo ello se podría añadir la progresiva secularización de las festividades religiosas del cristianismo, la ridiculización grosera o blasfema de sus símbolos o la batalla por excluirlos totalmente de la presencia pública, ya que supuestamente ofenderían los sentimientos de otros creyentes y de aquellas personas que no profesan ninguna religión; algunas formas de laicismo postcristiano resultan de hecho claramente anticristianas.

En resumen, nos encontramos con una parte de la cultura actual que puede calificarse de "postcristiana". Y no sólo por las dimensiones críticas aquí mencionadas a título ilustrativo, sino también por la convicción difusa de que el tiempo del Dios cristiano habría pasado y por la indiferencia religiosa, que conlleva desafección y desinterés. No resulta fácil medir las dimensiones reales del "postcristianismo" en un mundo cultural cuyas "raíces cristianas", evidentes en perspectiva histórica, no desaparecen porque la expresión se evite o no haya espacio para su mención en textos constitucionales. Sean cuales sean, no obstante, sus verdaderas dimensiones, el discurso creyente que quiere hacer valer a Dios como "sujeto" de la teología no puede ignorar la situación cultural y ha de confrontarse críticamente con ella. Sin aborrecer por esto la cultura contemporánea, donde el pluralismo religioso y cosmovisivo es tanto realidad fáctica como afirmación de principio.

Y debe hacerlo más aún cuando el elemento "postcristiano" de esta cultura configura una opinión mediática, bastante extendida y en muchos aspectos acrítica consigo misma, que tiene efectos narcotizantes no sólo ante la cuestión religiosa, sino también ante preguntas como el mal, la culpabilidad, la corresponsabilidad efectiva, la solidaridad real o la muerte cierta. Queda por ver si tales estupefacientes antirreligiosos tendrán largo alcance. Se integran, en todo caso, en los intentos por reconstituir un ateísmo, a veces militante, que se ve obligado por la fuerza de los hechos a reconocer el "retorno de lo religioso" y la crisis de la razón "secular". Estamos sin duda ante un fenómeno ambivalente, necesitado de discernimiento crítico. Pero no puede menos de sorprender a quien considere la fe cristiana sólo como una reliquia histórica del pasado: resulta que el Dios de la tradición cristiana, dado por "muerto" en repetidas ocasiones ${ }^{42}$, sigue respirando; el suyo es un "rumor inmortal" 43 .

\footnotetext{
42 Cf., A. GLUCKSMANN, La troisième mort de Dieu, Paris 2000 (trad. esp. La tercera muerte de Dios, Barcelona 2001); sobre la obra, cf. el comentario de P.G., "Dieu est-il mort en Europe?", Rech Sc Rel 88 (2000) 379-398; G. MUCCI, Dio non è ancora morto. Discussioni recenti, CivCatt $\mathrm{n}^{\circ} 3642$ (2002) 576-585; ID., Il Dio di A. Glucksmann, CivCatt no 3709 (2005) 54-60.

43 Así el título de la obra de R. SPAEMANN, Das unsterbliche Gerücht. Die Frage nach Gott und die Täuschung der Moderne, Stuttgart 2007, donde reedita (11-36) un artículo con el mismo
} 


\subsection{Una cultura "postsecular"}

El calificativo de "post-secular", aplicado también a una parte o a algunas tendencias de la sociedad y de la cultura contemporánea, es de acuñación más reciente, aunque su uso encuentra aceptación progresiva ${ }^{44}$. La utilización del mismo, sin embargo, pide algún tipo de esclarecimiento. Aquú lo empleamos en un doble sentido: para expresar las modificaciones en el ámbito de lo religioso, de que da cuenta la reciente sociología de la religión; para recoger la "conciencia de que algo falta" a la razón secular, tal como es reconocido por parte de pensadores "religiosamente no musicales".

Hasta hace no muchos años predominaba en el ámbito de la sociología religiosa la pregunta por el futuro de la religión, entendido como su posible desaparición en sociedades secularizadas. Y tal diagnóstico fue asumido, un tanto precipitadamente, también por algunos planteamientos teológicos. Se pensaba que el proceso de secularización era imparable y que los conocimientos científicos, los desarrollos tecnológicos, los cambios culturales y el progreso global irían arrinconando lo religioso y lo sagrado hacia el ámbito del obscurantismo, del folklore nostálgico y de la cultura marginal. Nadie hubiera dicho que se iba a producir la actual revancha de lo reprimido. Del "desencantamiento" del mundo (M. Weber) a un nuevo "reencantamiento" 45 .

La perspectiva actual de la sociología de la religión ya no es la de su disolución más o menos previsible, sino la pervivencia y transformación (metamorfosis) de lo religioso ${ }^{46}$. La sociología de la religión se cultiva ahora más allá del paradigma de la secularización como referencia decisi-

mismo título (Das unsterbliche Gerücht) publicado originariamente en un $\mathrm{n}^{\circ}$ especial de la revista "Merkur" 605-606 (1999) 772-783, dedicado al tema "Nach Gott fragen. Über das Religiöse".

44 Cf., H.J. HÖHN, Postsäkular. Gesselschaft im Umbruch - Religion im Wandel, Paderborn 2007; L: BOEVE, God interrupts History. Theology in a Time of Upheaval, New York 2007, que dedica la primera parte de su obra a la teología en un contexto "post-secular", si bien en el caso especial de Europa se trata para él de un fenómeno de "Detraditionalization" e "Individualization" de lo religioso.

45 Cf., M. GAUCHET, Le désenchantement du monde. Une histoire politique de la religion, Paris 1985; ID., Un monde désenchanté?, Paris 2007; F.A. ISAMBERT, Le "desenchantement" du monde: non sens ou renouveau du sens, Arch Sc Soc Rel 61/1 (1986) 83-103 (el no entero está dedicado al tema: "Societé moderne et Religion: autour de M. Weber").

46 Cf., B. FUEYO, Creencia en Dios y talante religioso actual, "Ciencia Tomista" 87 (1996) 201-255; J. MARTIN VELASCO, Metamorfosis de la religión y futuro del cristianismo, en S. DEL CURA ElENA (dir.), Sociedad y tendencias de futuro, Burgos 1998, 59-92; J. CASANOVA, Religiones públicas en el mundo moderno, Madrid 2000; Th. LUCKMANN, The Invisible Religion. The Transformation of Symbols in Industrial Society, New York 1963; más recientemente, cf. ID., Überlegungen zu den Metamorphosen der Religion in der Moderne, en E. TEUFEL (ed.), Was hält die moderne Gesellschaft zusammen?, Frankfurt 1996, 198-205. 
va o prevalente 47 , si bien se discute si Europa constituya o no un caso de excepción cuando se lo confronta, p.e., con la realidad norteamericana 48 . $\mathrm{Y}$ tales modificaciones sociológicas no pueden pasar desapercibidas a los teólogos: se impone un análisis más detallado de las variaciones de significado y de contenido de la secularización ${ }^{49}$; igualmente, un estudio más convincente del marco fundamental en el que comprender las relaciones entre secularidad y cristianismo ${ }^{50}$, así como una reflexión desapasionada sobre la posibilidad de haber desencadenado un proceso interno de "autosecularización" 51 por el señuelo de una acomodación (fácil y equivocada) de la fe cristiana a la cultura secular dominante.

Las metamorfosis en el panorama de lo "religioso" y de lo "sagrado" implican el reconocimiento de que la secularización no constituye la última palabra ${ }^{52}$. En los estudios de sociología religiosa, sin embargo, sigue siendo discutido el verdadero alcance de estas modificaciones: si bastan

47 Cf., P. GABRIEL, Religion und Gesellschaft revidiert. Anmerkungen zu einer Religionssoziologie jenseits des Säkularisierungsparadigmas, en K. FECHTNER u.a. (ed.), Religion wahrnehmen, Marburg 1996, 139-145; P. KOSLOWSKI, Die religiöse Dimension der Gesellschaft. Religion und ihre Theorien, Tübingen 1985; F.X. KAUFMANN, Religion und Modernität, Tübingen 1989; R. STARK - R. FINKE, Acts of Faith: Explaining the Human Side of Religion, Berkeley 2000; N. LUHMANN, Die Religion der Gesellschaft (ed. A. Kieserling), Frankfurt a.M. 2000.

48 Cf., G. DAVIE, Europe: The Exception that proves the Rule?, en P. BERGER (ed.), The Desecularization of the World: Resurgent Religion and World Politics, Grand Rapids 1999, $65-$ 83. El mismo P. Berger habla al respecto del contraste entre una subcultura minoritaria secularizada y un influjo muy grande de la misma: "There exists an international subculture composed of people with Western-type higher education, specially in the humanities and social sciences, that is indeed secularized. This subculture is the principal 'carrier' of progressive, Enlightened beliefs and values. While its members are relatively thin on the ground, they are very influential", en ID., o.c., 10. Para los cambios acontecidos también en el ámbito europeo, cf. Y. LAMBERT, A Turning Point in Religous Evolution in Europe, "Journal of Contemporary Religion" 19 (2004) 29-45. En lo referente a la situación española, cf. los datos ofrecidos por J. GONZALEZ ANLEO, La religiosidad española: presente y futuro, en O. GONZÁLEZ DE CARDEDAL (ed.), La Iglesia en España (1950-2000), Madrid 2000, 9-57; ID. - P. GONZÁLEZ BLASCO, Religión: Valores, ritos y creencias, en España 2000. Entre el localismo y la globalización, Fundación Santa María, Madrid 2000, 181- 215.

49 Cf.: H. LÜBBE, Säkularisierung. Geschichte eines ideenpolitischen Begriffs, Freiburg i.B. 1965; H. BLUMENBERG, Säkularisierung als Selbstbehauptung, Frankfurt a.M. 1974; K. DOBBELAERE, Secularization: A Multidimensional Concept, London 1981; G. MARRAMAO, Cielo e terra. Genealogia della secolarizzazione, Roma 1994; R. RÉMOND, Religion et societé en Europe. La sécularisation aux XIXe et XXe siècles (1780-2000), Paris 2001.

50 Cf., L. OVIEDO TORRO, La secularización como problema. Aportaciones al análisis de las relaciones entre fe cristiana y mundo moderno, Valencia 1990; ID., Secularización como contexto eclesial y de la reflexión teológica, "Antonianum" 70 (1995) 401-428; ID., La fe cristiana en las sociedades avanzadas: tensiones y respuestas, Madrid 2001; S. PIE I NINOT, Secularidad y cristianismo, en Presbiterado y Secularidad. Simposio, Madrid 1999, 19-3

51 El proceso habría tenido mayor amplitud en el ámbito protestante y proporciones menores en el ámbito católico, cf. Kl. NIENTIEDT, Selbstsäkularisierung, HK 52 (1998) 217-219.

52 Cf., F. W. GRAF, Die Wiederkehr der Götter. Religion in der modernen Kultur, München 2004. 
para confirmar que se está yendo más allá de la secularización en las complejas sociedades contemporáneas o si estas metamorfosis prolongan de hecho un proceso de secularización real bajo revestimientos sólo en apariencia religiosos ${ }^{53}$ : ¿hasta qué punto puede considerarse como "religión" aquello que aparentemente pervive o retorna como "religión"?

La pregunta está justificada, pues no sin motivos se habla de religiones de sustitución, mientras asistimos a reivindicaciones religiosas sin transcendencia o a propuestas de espiritualidades sin Dios ${ }^{54}$. La ambivalencia valorativa de los sociólogos 55 previene de este modo a los teólogos frente a valoraciones precipitadas, bien de derrotismo resignado ante las erosiones constantes de las religiones institucionales, bien de entusiasmo apologético ante las nuevas formas de religiosidad. De hecho, el contenido atribuible al concepto de "religión" puede variar hasta tal punto en la fenomenología y en la sociología que no tenga que ver con la idea de transcendencia divina. $\mathrm{Y}$ a la misma teología no le resulta fácil emitir un diagnóstico certero sobre la actual constelación místico-esotérica ni sobre las diversas mezclas de religiosidades y de espiritualidades ${ }^{56}$. Es posible que, en medio de sus ambivalencias y omisiones, pueda descubrirse en ellas la nostalgia de un Dios otro y distinto del acostumbrado, un Dios más sorprendente y con mayor fuerza de atracción; pero hay razones fundadas para considerarlas también en gran medida como otra expresión de la crisis radical del Dios revelado en Jesucristo.

53 Cf., U.H.J. KÖRTNER, Wiederkerh der Religion? Das Christentum zwischen neuer Spiritualität und Gottesvergessenheit, Gütersloh 2006; para una información de conjunto sobre las distintas valoraciones, cf. Renaissance der Religion: Mode oder Megatrend?, Herder Korrespondez Spezial (2006).

54 Cf. A. COMTE-SPONVILLE, L'esprit de l'athéisme. Introduction à une spiritualité sans Dieu, Paris 2007.

55 Cf., U. BECK, Der eigene Gott, Frankfurt a.M. 2008, 34-67.

56 Cf., E. GUERRIERO - A. TARZIA (ed.), I ritorni di Dio. Desideri e aporie della conscienza contemporanea, Torino 1994; J.M MARDONES, Para comprender las nuevas formas de religiosidad. La reconfiguración poscristiana de la religión, Estella 1994; ID., ¿A dónde va la religión? Cristianismo y religiosidad en nuestro tiempo, Santander 1996; R. DIAZ SALAZAR e.a., Formas modernas de religión, Madrid 1994; W.J. HANEGRAAFF, New Age Religion and Western Culture. Esotericism in the Mirror of Secular Thought, New York / Köln 1996; J. SUDBRACK, Esoterik als Religion, eine Herausdorderung, GuL 70 (1997) 323-336; M. PARMENTIER, A Chronology of the New Age Movement, "Bijdragen" 58 (1997) 426-436; B. J. HILBERATH, Religiosität ohne Gott? Rückfragen an philosophische und psycotherapeutische Konzepte, en G. AUGUSTIN - K. KRÄMER (eds.), Gott denken..., 73-88 
El término "post-secular", si bien ya se utilizaba por algunos en el campo teológico ${ }^{57}$, va unido especialmente al nombre de J. Habermas, quien recurre al mismo para expresar el cambio y la nueva configuración que ha adquirido la relación entre sociedad secularizada y religión en los últimos tiempos. Habermas calificó de "postseculares" a las sociedades modernas en su discurso del año 2001, al recibir el premio de los libreros alemanes $^{58}$. Él lo utilizó bajo el impacto causado por los atentados terroristas en Nueva York, el 11 de septiembre de 2001. Constataba así la pervivencia de la religión, precisamente como potencial amenazador y violento, en nuesto mundo globalizado; el fundamentalismo religioso aparecía como un fenómeno propio de la modernidad tardía, como una patología social de ella misma.

Pero en el ámbito de lo postsecular entra para Habermas ante todo una problemática que está pidiendo una nueva reflexión sobre la relación entre secularización y religión: el desarrollo de las ciencias bioéticas. Las posibilidades que se abren en este campo sacuden "la autoconciencia ética de la humanidad en su conjunto" y ponen en cuestión el "universalismo igualitario" que comprende a cada ser humano como igual entre iguales. Se trata de manipulaciones en la dotación genética de un ser humano, que terminan convirtiéndolo en "objeto" de finalidades ajenas a él mismo y haciendo de él una "cosa" y no una "persona" 59 . Con ello queda afectado gravemente un presupuesto moral básico para la convivencia pacífica en una sociedad moderna y pluralista. Y en este contexto contempla Habermas las religiones como un recurso potencial de racionalidad del que poder aprender, ya que ellas pertenecen también a la historia de la razón. Ante los nuevos desafíos pueden aportar una contribución esencial e incluso irrenunciable.

De ahí que Habermas abogue porque tampoco en las sociedades secularizadas se margine a la religión y se la excluya del discurso público,

57 A la "teología de la secularización" sucedió una "secularización de la teología", como afirmaba no hace mucho el teólogo protestante H.M. BARTH, Theologie der Säkularisation heute: Post-säkulare Theologie, NZSTh 39 (1997) 27-41; pero la situación actual es la de una "nueva secularidad": "Una nueva secularidad ha surgido, una secularidad que en modo alguno excluye la religiosidad. Para distinguirla de la secularidad precedente..., yo la denomino "post-secularidad" (ib. p. 31, trad. propia).

58 Cf., J. HABERMAS, Glauben und Wissen, Friedenspreis 2001, en ID., Zeitdiagnosen. Zwölf Essays, Frankfurt 2003, 249-262.

59 Cf., J. HABERMAS, Die Zukunft der menschlichen Natur. Auf dem Weg zu einer liberalen Eugenik?, Frankfurt a.M. 2002. 
para preservar así el "sentido humanitario" que contienen. Mediante el concepto de "sociedad postsecular" él quiere poner de manifiesto que se hace imprescindible un nuevo nivel de reflexión en la relación entre cultura secularizada y religión. Pues el proceso de secularización ha traído consigo no sólo ganancias, sino también pérdidas y amenazas. Y para no volverse ciegas ante este hecho, las sociedades secularizadas han de tomar en serio a las religiones e implicarlas en los procesos sociales. En esta perspectiva y ante tales "tendencias de una modernización que descarrilla" 60 , ésta no se puede identificar ya con una marginalización progresiva de la religión, sino con un proceso en el que permanece remitida a la herencia de lo religioso. A condición de que esta presencia pública y cultural de la religión en una sociedad pluralista no lesione los principios de la libertad y de la democracia.

Las propuestas acerca de la religión, hechas por J. Habermas en la fase más reciente de su pensamiento, han de ser ubicadas en el conjunto de su obra para percibir así sus pasos y modificaciones ${ }^{61}$. Hasta mediados de los años noventa son más bien escasas las exposiciones de carácter sistemático sobre el tema religión, limitándose a referencias indirectas en algunas obras. Así se hallan indicaciones sobre la función social de la religión bajo el signo de la tesis de la secularización (1981): la religión aparece únicamente como una fase histórica en el camino hacia una sociedad moderna y democrática, donde ha de tener vigencia el principio de la acción comunicativa ${ }^{62}$. Años más tarde (1988) explicita el reconocimiento de las tradiciones religiosas para la comprensión de conceptos centrales en la historia del pensamiento (un potencial semántico imprescindible), pero sin que la religión pueda exhibir ninguna pretensión de universalidad ni función alguna integrativa ${ }^{63}$.

Será ya desde mitad de los años noventa cuando trate explícitamente el tema religioso y se pregunte sobre todo por el papel de la religión en

\footnotetext{
60 Cf., J. HABERMAS, Ein Bewusstsein von dem, was fehlt. Über Glauben und Wissen und den Defätismus der modernen Vernunft, en K. WENZEL (ed.), Die Religionen und die Vernunft. Die Debatte um die Regensburger Vorlesung des Papstes, Freiburg i.B. 2007: él habla de "Tendenzen einer entgleisenden Modernisierung" (p. 51).

61 Para este itinerario, cf.: E. ARENS (ed.), Habermas und die Theologie. Beiträge zur theologischen Rezeption, Diskussion und Kritik der Theorie kommunikativen Handelns, Düsseldorf 1989, 11-17; S. MAY, Die Rolle der Religion in der postsäkularen Gesellschaft. Zur Religionsphilosophie von J. Habermas, Th Ph 80 (2005) 546-665.

62 Cf, J. HABERMAS, Theorie des kommunikativen Handelns, vol. 2, Frankfurt a.M. 1981, 103, 118.

63 Cf., J. HABERMAS, Nachmetaphysiches Denken, Frankfurt a.M. 1988.
} 
sus presupuestos fundamentales de tipo ético y social: aquí se ubican el discurso con ocasión del premio K. Jasper (1995), el discurso ya mencionado con ocasión del premio de la paz (2001) y la discusión con el entonces cardenal J. Ratzinger (2004) ${ }^{64}$. En todos ellos retornan las ideas de que la religión encierra un recurso moral importante, de que es necesario hacer accesibles a la razón secular los contenidos del lenguaje religioso, de que se da una referencia recíproca entre creer y saber, de que los proyectos religiosos de vida juegan un papel importante también en democracias deliberativas a condición de que no se erijan en expedientes normativos. Sus textos más importantes para el tema religioso entre 2000 y 2005 se hallan reunidos en un volumen ${ }^{65}$ donde destaca su trabajo sobre la comprensión de la religión en E. Kant; a este respecto Habermas mantiene que son cosas muy distintas la fundamentación de la moral y la de la existencia de Dios, que se ha de mantener la distinción neta entre creer y saber y que la religión ha de comprenderse en último término como algo exterior a la filosofía. En el transfondo y en continuidad con estos últimos trabajos se ha ubicar el artículo sobre la "conciencia de aquello que falta" $(2007)^{66}$, reflexión de interés para filósofoso y teólogos ${ }^{67}$ por parte de un pensador que se retiene a sí mismo como alguien "religiosamente no musical" 68 . No es éste el lugar para una discusión con las diversas fases y articulaciones del pensamiento de Habermas a propósito de la religión. Quede únicamente constancia del alcance que otorga a la condición de una sociedad "postsecular", de la necesidad improrrogable de que creer y saber lleven a cabo un proceso de aprendizaje recíproco y de la tarea pendiente que propone a la teología: traducir en términos de razón secular los contenidos religiosos de la fe cristiana69.

A mí me parece que tanto las metamorfosis de lo religioso como el

64 Cf., J. HABERMAS - J. RATZINGER, Dialektik der Aufklärung, Freiburg i.B. 2004 (Cf. la trad. española, con prólogo de L. Rodríguez Duplá, Dialéctica de la secularización. Sobre la razón y la religión, Madrid 2006).

65 Cf., J. HABERMAS, Zwischen Naturalismus und Religion, Frankfurt a.M. 2005.

66 Cf. el título del art. en n. 60, cuya primera versión fue publicada en el "Neue Zürcher Zeitung" (10.02.07). Este art. ha sido objeto de una discusión reciente, cf. M. REDER - J. SCHMIDT (eds.), Ein Bewusstsein von dem, was fehlt. Eine Diskussion mit J. Habermas, Frankfurt a.M. 2008, acompañada de una respuesta del mismo J. Habermas (pp. 94-107).

67 Cf.: el Simposio mantenido en Viena en 2005, R. LANGTHALER - H. NAGL-DoCEKAL (eds.), Glauben und Wissen. Ein Symposium, Wien 2007, con una amplia réplica de J. Habermas a las distintas intervenciones (pp. 366-414); al respecto, cf. H.L. OLLIG, Habermas im Religionsdiskurs, ThPh 83 (2008) 410-425.

68 La expresión proviene de Max Weber; cf. al respecto, N. BoLZ, Das Wissen der Religion. Betrachtungen eines religiös Unmusikalischen, München 2008.

$69 \mathrm{Cf}$. indicaciones al respecto en M. KNAPP, Glauben und Wissen bei J. Habermas. Religion in einer "postsäkularen" Gesellschaft, "Stimmen der Zeit" 4 (2008) 270-280. 
proceso del pensamiento de Habermas obligan a que la teología repiense a Dios hoy día no sólo en el contexto de crítica post- o antirreligiosa, sino también en el contexto posterior a la crítica de la religión. Mirando hacia atrás, hacia lo que ha sido durante muchos siglos el itinerario histórico del pensamiento, nos es lícito afirmar: la cuestión de Dios, con todas sus variaciones en la forma de plantearla y de responderla, ha sido una constante en la historia de la filosofía y en la temática de pensadores. Será desde una época más bien reciente, al hilo de la Ilustración moderna, a través del positivismo, del materialismo y de las diversas formas de ateísmos, como se produzca una ruptura con esta tradición. Hoy, ciertamente, no es ya un ateísmo teórico, filosóficamente fundado, lo que ocupa el interés primordial del pensamiento filosófico. Pero de los temas centrales de su repertorio no puede decirse que, en gran medida, forme parte generalmente la cuestión de Dios. Ésta es más bien silenciada, como si Dios no fuera merecedor de una pregunta por parte de determinadas corrientes filosóficas, de gran influjo y difusión. Como si el destino suyo estuviera unido irremediablemente a la suerte de la metafísica, cuyo fin viene siendo tan reiteradamente anunciado como desmentido.

La mención de J. Habermas ilustra, sin embargo, que el silenciamiento de la religión no caracteriza por completo el panorama filosófico contemporáneo. Y tampoco la caracteriza el silenciamento de Dios ${ }^{70}$. La lista que lo desmiente podría ser numerosa. Todo lo cual no impide sostener que, por caminos distintos y a veces sorprendentes, para la pregunta por Dios hay también lugar en esta situación paradójica de postcristianismo y postsecularización. Es decir, que el Dios revelado en Jesucristo sigue siendo pensable y vale la pena el esfuerzo de pensarlo. No otra cosa sino responder a este estímulo es lo que se intenta a continuación, al buscar poner de relieve algunos elementos de la significatividad de Dios como "sujeto" de la teología.

\section{La relevancia o significatividad}

Que Dios sea y haya de ser "sujeto" de la teología es una tesis con relevancia permanente para la autocomprensión del quehacer teológico. Una relevancia que en la teología cristiana alcanza su especificidad propia en el hecho de que el Dios "sujeto" es precisamente Dios Padre, reve-

\footnotetext{
70 Cf. mi art. A tiempo y a destiempo..., cit. supra n. 3, bajo el parágrafo "Dios da que pensar", pp. 23-28.
} 
lado en el acontecimiento Jesucristo y en el don del Espíritu Santo. Ahora se trata de ver cuál puede ser el alcance de la tesis en el contexto cultural en que vivimos, caracterizado al mismo tiempo de postcristiano y postsecular. No es posible aquí, sin embargo, un tratamiento amplio y pormenorizado de esta incidencia ${ }^{71}$. Por ello, la relevancia de Dios como "sujeto" de la teología quedará circunscrita a los siguientes aspectos: la primacía de Dios, la verdad de Dios y el Misterio de Dios.

\subsection{La primacía de Dios}

Para la teología cristiana la realidad de Dios como el primero en todo, aquel de quien parte toda iniciativa y todo don gratuito, se corresponde con la precedencia de la Palabra revelada respecto a toda palabra humana y con la respuesta de la fe como escucha y obediencia a la revelación de Dios (ob-audire). Revelación y fe son así presupuestos y elementos estructurantes de la teología cristiana, que no puede proceder sino reconociendo a Dios su condición de anterioridad y preeminencia. Por ello, hacer valer esta primacía de Dios en el momento presente no es sino continuar una tarea determinante del quehacer teológico, modulada ahora por las circunstancias de un contexto profundamente modificado.

En el método teológico, escuchar la Palabra de Dios tiene para la teología cristiana un carácter fundante. Se trata de la Palabra de Dios hecha carne y comunicada definitivamente en el acontecimiento Jesucristo, Palabra que existía en el principio, que estaba junto a Dios y era Dios, que es luz y vida para los hombres (cf. Jn 1,1-18). Palabra de Dios que nos es accesible y elocuente en el don del Espíritu Santo, el cual la inscribe en las palabras humanas de los autores bíblicos y posibilita que sea reconocida como Palabra de Dios por parte de quien la lee en actitud creyente.

De ahí que, ante la precedencia de la revelación, la respuesta adecuada sea la de la fe: "Porque, si confiesas con tu boca que Jesús es el Señor y crees en tu corazón que Dios le resucitó de entre los muertos, serás salvo; pues con el corazón se cree para conseguir la justicia, y con la

\footnotetext{
71 Aunque en ellas no se trata directamente la cuestión de Dios como "sujeto" de la teología, hay indicaciones y estímulos valiosos a este respecto en las siguientes obras: P. WALTER (ed.), Gottesrede in postsäkularer Kultur, Freiburg i.B. 2007; L. BOEVE, God interrupts History. Theology in a Time of Upheaval, New York 2007; H.J. HÖHN, Der fremde Gott. Glaube in postsäkularer Kultur, Würzburg 2008.
} 
boca se confiesa para conseguir la salvación" (Rm 10,9s.). Una fe que es al mismo tiempo profundamente personal (yo creo) y eclesial (nosotros creemos), tanto expresión de una entrega y compromiso subjetivo (fides qua) como aceptación de unos contenidos creyentes nuclearmente recogidos en las profesiones de fe (fides quae), tanto experiencia de la salvación de Dios como conocimiento de la verdad salvífica divina.

Siendo así, la precedencia de la revelación implica que la teología haga valer siempre la primacía de Dios y que, en razón de ésta, el quehacer teológico se convierta en un ejercicio de escucha atenta y de obediencia creyente ${ }^{72}$. En un doble movimiento de circularidad que va de la fe a la inteligencia y de la inteligencia a la fe: una fe que busca su propia inteligibilidad (credo ut intelligam), estimulando así la reflexión y la pregunta de la teología; un entender orientado hacia la fe (intelligo ut credam), que en su búsqueda pretende comprender la fe precisamente en cuanto fe. Nada más acertado que citar al respecto al gran $\mathrm{S}$. Agustín como testigo preclaro de esta relación inescindible y recíproca entre fe e inteligencia, creer y pensar, buscar y encontrar ${ }^{73}$.

La precedencia de la revelación y la primacía de Dios, la fe como respuesta y la teología como escucha obediente harán valer la condición de Dios como «sujeto» de la teología en su relevancia para el momento actual. Pues también el nuestro es un tiempo para hablar de Dios, para pensar en Dios y para pensar a Dios ${ }^{74}$. Y ésta es una tarea tanto más urgente cuanto mayor es su pérdida de plausibilidad, más acuciante el desafío de su transmisión creíble y más difusa la presión ambiental a favor de su silenciamiento. Un hablar y pensar llevado a cabo desde la implicación subjetiva y cordial, no desde la neutralidad distanciada y descomprometida. Tenemos motivos de sobra para hablar de Dios, para pensar en Dios y para pensar a Dios, de modo que siempre tenga vigor su primacía divina. En rigor, no tenemos otra cosa que buscar, creer y testimoniar,

\footnotetext{
72 Cf., al respecto, Dei Verbum 5, en referencia al Vaticano I, Dei Filius 3, DH 3008.

73 "Fides nisi cogitetur nulla est. Nullus quippe credit aliquid, nisi prius cogitaverit esse credendum», en De praedestinatione sanctorum», PL 44,963, 962; "Quaeramus inveniendum, quaeramus inventum. Ut inveniendus quaeratur, occultus est; ut inventus quaeratur, immensus est", en In Johannis Evang., LXIII, 1. PL 35, 1805.

74 Cf., S. DEL CURA ELENA, A tiempo y a destiempo..., cit. supra n. 3. En el volumen, ya citado anteriormente, en homenaje al cardenal W. Kasper, se incluyen numerosos trabajos dedicados a la tarea de pensar y testimoniar a Dios, cf. G. AUGUSTIN - K. KRÄMER (eds.), Gott denken und bezeugen. Festschrift für Kardinal Walter Kasper zum 75. Geburtstag, Freiburg i.B. 2008.
} 
también en la situación cultural contemporánea. ¿Cómo podríamos resignarnos entonces a guardar solamente silencio, por muy respetuoso que fuera, a dejar que la teología se vea afectada de afasia paralizante o a identificar el respeto debido a Dios con indolencia intelectual?

Pero esta convicción no impide, sino que más bien estimula la atención debida a aquellos elementos de la cultura actual que hemos calificado de postcristiana, en cuanto marcada por la crítica atea, la indiferencia religiosa y el olvido de Dios. El concilio Vaticano II (GS 19-21) hizo un gran esfuerzo por justificar y mantener una actitud dialogal con el ateísmo y por comprenderlo objetivamente, individuando sus causas y motivos ${ }^{75}$. Ello hace que el ateísmo aparezca como un fenómeno no originario, sino secundario y derivado. Pero uno de los aspectos más llamativos es la explicación genealógica del mismo como una reacción crítica frente a la religión en general y frente al cristianismo en particular, e.d., la consideración del ateísmo como un fenómeno post-religioso y post-cristiano (cf. GS 19).

Me parece importante retener esta interpretación histórico-genética del ateísmo, a condición de no hacer de ella su clave hermeneútica determinante y exclusiva, pues en el origen de la negación de Dios han intervenido también otros factores (anticristianos y extracristianos). Pero, en cualquier caso, no queda sino reiterar una vez más la función purificatoria que respecto a nuestras imágenes, conceptos y vivencias de Dios puede desempeñar la crítica de la religión ${ }^{76}$. Como una función necesaria, incluso como una dimensión profética que ayuda a purificar las expresiones de fe y el discurso teológico. Una crítica que puede dejar abierto un espacio de interrogación, un lugar de credibilidad para la fe, una posibilidad de ésta liberada de su identificación con una expresión cultural históricamente determinada ${ }^{77}$.

75 Para una valoración de su recepción postconciliar, a 40 años del Vaticano II, cf. el comentario de H.J. SANDER, Theologische Kommentar zur Pastoralkonstitution über die Kirche in der Welt von heute "Gaudium et spes", en P. HÜNERMANN - B.J. HILBERATH (eds.), Herders Theologischer Kommentar zum zweiten Vatikanischen Konzil, vol. 4, Freiburg i.B. 2005, 729-742.

${ }^{76}$ La crítica de las falsas imágenes de Dios no ha de retenerse como una aportación exclusiva de los diversos ateísmos, es también tarea de la propia fe cristiana en el Dios vivo y verdadero; cf. K. FRIELINGSDORF, Dämonische Gottesbilder. Ihre Entstehung, Entlarvung und Uberwindung, Mainz 1992; ID., Der wahre Gott ist anders. Von krankmachenden zu heilenden Gottesbildern, Mainz 1997; J. MüLLER, Gott ist anders. Das Leiden an den falschen Gottesvorstellungen, Stuttgart 1993.

77 Cf: A. CHARRON, La critique de la religion, une fonction mal reconnue, "Sciencie et Esprit" 38 (1986) 151-179; H. GROOS, Christlicher Glaube und intellektuelles Gewissen, Tübingen 1987; F. VARONE, El Dios ausente. Reacciones religiosa, atea y creyente, Santander 1987. 
El reconocimiento de esta función purificatoria va implícito en las palabras del Vaticano II, cuando asegura que "en la génesis del ateísmo pueden tener parte no pequeña los propios creyentes, en cuanto que, con el descuido de la educación religiosa o con la exposición inadecuada de la doctrina, o incluso con los defectos de su vida religiosa, moral y social, han velado más bien que revelado el genuino rostro de Dios y de la religión" (GS 19). Reconocer, entonces, la propia responsabilidad en el origen de la negación de Dios, llevará a los creyentes a dos tareas primordiales: rehacer el discurso teológico y la praxis vital, para que Dios pueda aparecer como plenitud existencial del ser humano; dejarse habitar por la experiencia religiosa, pues solamente los "habitados" por ella serán capaces de transmitir y de comunicar el gusto por la realidad de Dios en un mundo marcado por su olvido o desinterés ${ }^{78}$.

Motivos para hacer valer la primacía de Dios los ofrece igualmente la cultura calificada de postsecular. De algún modo puede compararse esta cultura con la efervescencia religiosa y espiritual de los primeros siglos. Ante ella, la fe cristiana se comportó de manera más bien austera y rigurosa (cf. Col 2, 16-17): sólo Cristo, Verbo de Dios, merece fe y confianza, porque sólo él es el enviado del Padre. Esta austeridad permitió a las comunidades cristianas desmarcarse de los sueños milenaristas, de las fábulas gnósticas y de las prácticas esotéricas. Todo ello como consecuencia de la sobriedad de la fe en Cristo: el único misterio de Dios Padre se ha manifestado en la vida de Jesús y se ha revelado en el Espíritu. Que Dios en su Hijo se hiciera uno de nosotros fue la norma para discernir todo lo que la imaginación religiosa proponía entonces. Y también el medio para evitar que Cristo fuera reinterpretado a partir de un camino distinto del que él mismo había trazado y que le había conducido a la muerte en cruz.

77 Cf.: A. CHARRON, La critique de la religion, une fonction mal reconnue, "Sciencie et Esprit" 38 (1986) 151-179; H. GROOS, Christlicher Glaube und intellektuelles Gewissen, Tübingen 1987; F. VARONE, El Dios ausente. Reacciones religiosa, atea y creyente, Santander 1987.

78 Sobre las distintas formas de afrontar teológicamente el ateísmo en la situación española, cf. mi trabajo, S. DEL CURA ELENA, Ateísmo e increencia como tema de la teología. Algunas características de su desarrollo en España (1965-1987), "Salmanticensis" 35 (1988) 201-241 (allí bibl. abundante sobre el tema). Aunque no es éste el lugar para hacerlo, valdría la pena prolongar este trabajo para los veinte años que van desde entonces hasta hoy, dados los cambios profundos que han acontecido en nuestro propio contexto; cf., entre otros, J.I. GONZALEZ FAUS - I. SOTELO, ¿Sin Dios o con Dios? Razones del agnóstico y del creyente, Madrid 2002; J.M. MARDONES, La indiferencia religosa en España, Madrid 2004. 
Se trataba no tanto de un juicio despreciativo sobre religiosidades sincretisas o exacerbadas, cuanto de preservar algo original: el camino de un Dios transcendente que se revela en lo más humano y en lo más humilde. Esta regla de sobriedad sigue siendo hoy día pertinente, pues en esta cultura postsecular nos encontramos con una religiosidad de deificación de la vida misma en cuanto tal, del sentirse a gusto, de la autorrealización individual o elitista, que no responde a la primacía de Dios y resulta profundamente extraña a una salvación gratuita, cuyo reino se funda sobre la cruz de Cristo y sobre la victoria de la resurrección. Un Dios que, revelado en Cristo, desenmascara las ambigüedades demasiado humanas de lo "religioso" y de lo "sagrado".

Dicha sobriedad no basta, ciertamente, por sí sola como respuesta a las exigencias de algunos contemporáneos nuestros, en cuya religiosidad será necesario buscar puntos de encuentro para hacer valer también en este caso la primacía de Dios. Pero esta necesidad lleva a tener en cuenta dos hechos que van unidos: por un lado, el reconocimiento de que las actuales metamorfosis de lo religioso desmienten que la cuestión de Dios haya de considerarse definitivamente liquidada por el peso de la crítica atea o la difusión de la indiferencia religiosa; por otro lado, la urgencia de un discernimiento teológico de estas metamorfosis, para esclarecer si el retorno de lo religioso deja espacio para un Dios divino, transcendente y personal o se diluye en una religiosidad inmanente, donde la primacía y la preeminencia corresponden con claridad al yo subjetivo y a todo lo relacionado con un ego-centrismo casi connatural al hombre contemporáneo. Sobre este discernimiento volveré en el punto siguiente.

Para concluir con éste baste recordar, aunque pueda resultar llamativo, que hacer valer la primacía de Dios tiene incidencia también en los ámbitos intracristianos y en el comportamiento de las iglesias. Yo tengo la impresión de que en la praxis cristiana se olvida a veces dicha primacía o se funciona envueltos en una nebulosa, de la que desaparece cualquier referencia explícita a la realidad de Dios. Según encuestas de opinión pública, se tiene la percepción de hablar mucho sobre las cosas que la iglesia hace $u$ organiza, pero muy poco sobre cuestiones de fe y sobre la realidad de Dios ${ }^{79}$; organizaciones surgidas en el seno del cristianismo o instituciones originariamente de carácter eclesial prefieren acomodarse en sus denominaciones y en su funcionamiento al marco y a los criterios de las

79 Cf., Die Kirchen sprechen zu wenig von Gott. Interview mit der Allensbacher Meinungsforscherin R. Köcher, en "Kath. Kirchenzeitung Berlin", 32 (9.8.1998), 5. 
diversas ONGs, de orientación solidaria y humanista ${ }^{80}$; hay ciertos temas "malditos" en la catequesis contemporánea (p.e., la pregunta por Dios o la esperanza de vida eterna) o programaciones de catequesis de confirmación, cuya divisa es "no hablar sobre Dios, sino sobre la vida" 1 ; en algunas celebraciones litúrgicas, por la superabundancia de palabras 82 o por las diversas funcionalizaciones de la misma liturgia, no se sabe muy bien si en último término nos celebramos repetitivamente a nosotros mismos (nuestros sentimientos, nuestra cultura, nuestras necesidades, nuestras tradiciones) o si allí queda verdadero espacio para presentir y sobrecogerse ante el Misterio de Dios que nos envuelve, nos desborda y nos transciende 83 .

Con todo ello únicamente quiero recordar que si la primacía de Dios se difumina o si el nombre de Dios termina convirtiéndose en algo sustituíble o intercambiable sin más con otra multitud de nombres, terminará lógicamente siendo sustituído. Y, por otra parte, cuando las iglesias cristianas se vacían de su propia substancia y terminan relegando a un lugar secundario al Dios a quien corresponde toda preeminencia, se quedan sin capacidad de reacción ante los acontecimientos que les sobrevienen, limitándose a reaccionar con mayor o menor diplomacia, a buscar compromisos de supervivencia o a sacrificar lo esencial con tal de sobrevivir a cualquier precio. No deja de ser ilustrativo que en los difíciles momentos del nacionalsocialismo fuera precisamente $\mathrm{K}$. Barth, el defensor a ultranza de la santidad, de la transcendencia y de la divinidad de Dios, uno de los teólogos que viera con más lucidez la gravedad de la situación y el que demostrase mayor libertad y valentía en aquellas circunstancias tan confusas y tan dramáticas. Hacer valer la primacía de Dios es luchar a favor de la dignidad y de la libertad humana.

\subsection{La Verdad de Dios}

La condición de Dios como "sujeto" de la teología lleva a que ésta sirva ante todo a la realidad y a la verdad de Dios, pues la "diaconía de la

\footnotetext{
${ }^{80}$ Esto no es ninguna crítica a las diversas ONGs, sino constación de un proceso interno a algunas instituciones cristianas, que bien merece un análisis detenido.

${ }^{81} \mathrm{La}$ referencia la tomo de A. HEINZ, Eröffnungswort, LJ 51 (2001) 3 n. 4.

82 Aunque sea muy radical, conviene tener en cuenta la crítica de A. LORENZER, Das Konzil der Buchhalter. Die Zerstörung der Sinnlichkeit. Eine Religionskritik, Frankfurt a.M. 1984.

83 Cf., D.N. POWER, La experiencia de Dios en la liturgia cristiana, "Concilium" n' 289 (2001) 14 y también M. ROONEY, Gotteserfahrung und liturgisches Gebet, GuL (2000) 106-120.
} 
verdad", responsabilidad eminente de la Iglesia para con los hombres según Fides et ratio ${ }^{84}$, compendia también el sentido del quehacer teológi$\operatorname{co}^{85}$. Respondiendo a esta vocación la teología sirve a la verdad de Dios, que es para los hombres fuente de libertad y salvación. Y esta responsabilidad es acorde con el designio divino, pues, Dios quiere que todos los hombres se salven y lleguen al conocimiento pleno de la verdad" (1Tm 2,4). Una verdad que no es sino la verdad de Dios Padre, Hijo y Espíritu Santo. Una verdad comunicada en la historia de la salvación y accesible en la fe. Una verdad que además de ser creída necesita ser pensada, pues de lo contrario la fe se desvanece en nulidad 86 .

Para ello, el acontecimiento Jesucristo y el don del Espíritu Santo constituyen el punto de partida y la norma de referencia. He aquí la guía orientativa de toda teología cristiana. Jesucristo, en su concreción histórica de Hijo enviado por el Padre (cf. Ga 4, 4-6) y hecho carne en las entrañas de María Virgen por obra del Espíritu Santo (cf. Lc 1,35; Mt 1, 20 ), es al mismo tiempo la verdad (Jn 14,6) y el testigo de la verdad (Jn 18,37) ${ }^{87}$. A su vez el Espíritu Santo, Don divino por antonomasia (cf. Lc 11,13), es para los creyentes el paráclito que los consuela y el Espíritu de la verdad (Jn 14,17) que ilumina su existencia e inspira su comportamiento. Todo lo cual tiene en Dios Padre la fuente primera de la iniciativa salvífica (cf. Ga 4,4s) y la meta última de su consumación definitiva (cf. Ap 21,5-7). Entonces la revelación escatológica de la verdad de Dios coincidirá con la plenitud última de los hombres y de la creación entera (cf. 1Co $15,28)$ y se hará manifiesto en su definitividad que la verdad de nuestra salvación es la verdad de Dios Padre, Hijo y Espíritu Santo.

Bien puede decirse, en consecuencia, que la realidad trinitaria de Dios representa el contenido y la estructura de la revelación divina en cuanto salvación de los hombres. Y que este misterio deberá ser el centro de la reflexión teológica ${ }^{88}$. Para la teología cristiana la verdad de Dios y la

84 Cf., Fides et Ratio, $\mathrm{n}^{\circ} 2$ y n $^{\circ} 6$ en continuidad con Veritatis splendor (1983).

85 Cf., la Instrucción "Donum veritatis" (1990) sobre la vocación eclesial del teólogo, acompañada de comentarios respectivos, publicada por la Ed. Vaticana, Città del Vaticano 1993.

86 "Et ipsum credere, nihil aliud est, quam cum assensione cogitare ... Omnis qui credit, et credendo cogitat, et cogitando credit ... quoniam fides si non cogitatur nulla est", $S$. AGUSTIN, De fide, spe et caritate, 7, CCL 64,61.

87 Para la reflexión agustiniana y tomasiana sobre estas afirmaciones de $\mathrm{Jn}$, cf. R. FERRI, Gesù e la verità. Agostino e Tommaso interpreti del Vangelo di Giovanni, Roma 2007.

88 Así lo sostiene Fides et ratio $\mathrm{n}^{\circ} 93$. 
salvación del hombre sólo pueden ser creídas, vividas y pensadas en una fe trinitaria; la verdad cristiana tiene un ritmo trinitario ${ }^{89}$. La validez de este principio está corroborada por la historia de la teología en el pasado y en el presente. Los caminos teológicos, al articular argumentativamente la estructura trinitaria de la verdad, pueden sin duda ser distintos; pero en su diversidad confirman la validez del principio trinitario ${ }^{90}$.

Así, por un lado, al margen del acontecimiento Jesucristo toda elaboración de un discurso trinitario resultaría extraña a las fuentes bíblicas y se resolvería en abstracción especulativa. A su vez, sólo en una fe trinitaria es posible reconocer a Jesucristo como el Señor, el Hijo de Dios y el Salvador de los hombres ${ }^{91}$. Sólo en esta fe se puede rendir gloria y alabanza al Espíritu Santo, en cuanto Espíritu del Padre y del Hijo, Espíritu que santifica y es dador de vida92. Sólo en esta fe puede creerse en Dios Padre como creador omnipotente y plenificador último. Para acreditarse en el ámbito cristiano, por tanto, toda propuesta teológica deberá asumir la verdad del Dios trinitario como el Dios de nuestra salvación ${ }^{93}$.

Pero pensar a Dios como verdad trinitaria no es sino pensarlo como amor (cf. 1Jn 4,8.16): amor en sí que hace posible su ser amor hasta el final en favor de los hombres. Lo uno incluye lo otro. La identidad de la teología cristiana está así determinada fundamentalmente por la realidad del Dios trinitario: Dios es amor y es verdad, o dicho de otra manera, la verdad del Dios trinitario es la verdad de su amor. Hacerlo valer en la comprensión y transmisión del designio salvífico universal es una tarea tan ineludible como prometedora para el quehacer teológico de hoy.

89 Cf., B. D. MARSHALL, Trinity and Truth, Cambridge 2000; B. BENATS, Il ritmo trinitario della verità. La teologia di Ireneo di Lione, Roma 2006.

90 Cf., S. DEL CURA ElENA, Discurso sobre Dios y misterio trinitario, "Estudios Trinitarios" 25 (1991) 247-456; J. THOMPSON, Modern Trinitarian Perspectives, New York 1994; Ch. SCHWÖBEL, Trinitarian Theology Today, Edinburgh 1995; N. CIOLA, Teologia trinitaria. Storia, metodo, prospettive, Bologna 1996; E. SCOGNAMIGLIO, La Trinità nellla passione del mondo, Milano 2000; A. HUNT, Trinity, New York 2005; M. WELKER - M. VOLF (eds.), Der lebendige Gott als Trinität, Gütersloh 2006; E. DURAND - V. HOLZER (dir.), Les sources du renouveau de la théologie trinitaire au Xxe siécle, Paris 2008.

91 Este fe queda expresada, recogiendo el sentir de la tradición bíblica, en la confesión del concilio I de Nicea (325), cf. DH 125.

92 Así en la ampliación pneumatológica añadida por el concilio I de Constantinopla (381), cf. DH 150.

93 Cf. lo que en referencia a los misterios de la Encarnación y de la Trinidad dice la declaración Mysterium Filii Dei (1972) nº 6 y 7. 
La responsabilidad de la teología para con esta verdad del Dios trinitario se ejerce en medio del debate contemporáneo sobre las diversas formas de racionalidad y de nociones de verdad ${ }^{94}$. No todas son igualmente válidas en el discurso teológico, pues sin una cierta comprensión realista y referencial de la verdad ${ }^{95}$ no se puede mantener la naturaleza de las aserciones creyentes en su carácter objetivo, universal y permanente ${ }^{96}$. Resultan insuficientes, por ello, las comprensiones meramente pragmáticas, empiristas, funcionales, subjetivas, consensuadas, constructivistas o historicistas de la verdad. Es decir, aquellas que no garantizan la identidad de un depositum fidei mantenido a través de generaciones, épocas y culturas. Ello no impide que la teología asuma los elementos justamente acentuados en estas comprensiones: la superación de un realismo cognitivo ingenuo, la importancia de la tradición en el conocimiento, la implicación subjetiva de quien conoce, la influencia de los paradigmas culturales, la necesidad de un proceder hermeneútico adecuado en la interpretación de la verdad, el desenmascaramiento de supuestas neutralidades y de intereses ideológicos. Pero, en medio de estas asunciones, la teología ha de mantener que sus afirmaciones sobre Dios son no sólo significativas, sino también verdaderas ${ }^{97}$ y que el núcleo substancial de la verdad revelada de Dios es válido en toda época, cultura y contexto.

A este respecto tiene especial relieve para la teología en nuestra cultura postcristiana y postsecular el debate sobre la relación entre verdad y tolerancia o intolerancia. Pues es cierto que la invocación de la verdad del Dios único ha podido legitimar determinados comportamientos intole-

94 Cf.: C. GEFFRE, La question de la vérité dans la théologie contemporaine, en M. MICHEL (ed.), La théologie à la épreuve de la vérité, Paris 1984, 281-291; A. GESCHE, Théologie de la vérité, RevThLouv 18 (1987) 187-211; E. CORETH (ed.), Wahrheit in Einheit und Vielheit, Düsseldorf 1987; A. KREINER, Ende der Wahrheit? Zum Wahrheitsverständnis in Philosophie und Theologie, Freiburg 1992; L.B. PUNTEL, Wahrheitstheorien in der neueren Philosophie. Eine kritisch-systematische Darstellung, Darmstadt 1993 ( $3^{\mathrm{a}}$ ed.); ID., Der Wahrheitsbegriff in Philosophie und Theologie, ZThK, Beiheft 9 (1995) 16-45; J.S. O'LEARY, La vérité chrétienne à l'âge du pluralisme religieux, Paris 1994; A. MILANO, Quale verità. Per una critica della ragione teologica, Bologna 1999; I.U. DALFERTH - P. STOELLGER, Wahrheit, Glaube und Theologie. Zur theologischen Rezeption zeitgenössicher wahrheitstheorethischer Diskussionen, ThRd 66 (2001) 36-102; de gran interés son los distintos trabajos pubicados por la "Revue Thomiste" 104 (2004) 5-352.

$95 \mathrm{Cf}$., Fides et ratio $\mathrm{n}^{\circ} 82$.

96 Cf., Th. G. GUARINO, Foundations of Systematic Theology, New York 2005, 73-140.

97 Cf., Fides et ratio $\mathrm{n}^{\circ} 84$.

98 Cf.: S. DEL CURA ELENA, Monoteísmo, (in)tolerancia y nuevas mitologías, en F. GARCIA - J.I. TELlECHEA, Tolerancia y fe católica en España, Salmanca 1996; Th. SÖDING (ed.), Ist der Glaube Feind der Freiheit? Die neue Debatte um den Monotheismus, Freiburg i.B. 2003; P. WALTER (ed.), Das Gewaltpotential des Monotheismus und der dreieine Gott, Freiburg i.B. 
rantes o justificar actitudes violentas ${ }^{98}$. Pero, en rigor, sólo la verdad absoluta, es decir, sin ataduras, hace realmente libres. Y la teología está obligada a poner de manifiesto que la verdad de Dios no sólo libera efectivamente, sino que garantiza radicalmente la libertad de los hombres ${ }^{99}$.

Hacer valer la verdad de Dios con estas pretensiones implica para la teología afrontar las dificultades propias del momento presente, ya que sin afrontarlas no podría ejercer su servicio específico. Estas dificultades proceden de motivaciones diversas, aunque relacionadas entre sí. Baste recordar algunas: la desconfianza en la posibilidad de conocer la verdad, sobre todo cuando se presenta como definitiva y absoluta; la idea de que una comprensión de la verdad vinculada a presupuestos metafísicos pertenecería a épocas del pasado ya superadas; la tesis de que, mientras mantenga esta vinculación, la teología será radicalmente incapaz de sintonizar con los desafíos del pensamiento moderno y postmoderno; las deficiencias del discurso teológico que ignoraría la historicidad radical de todo conocer, sus condicionamientos sociales y culturales, los elementos subjetivos determinantes, la complejidad de los procesos hermeneúticos, la finitud radical de las capacidades humanas o las dimensiones prácticas de la verdad.

De ahí la opción de algunas corrientes del pensamiento contemporáneo por un relativismo historicista radical, que precisamente en sus pretensiones absolutas resulta insostenible y que la teología no puede hacer suyo. Pero también otras formas menos radicales, en las que se proponen comprensiones flexibles y falibilistas de la verdad, abiertas a una revisión ulterior continua, expresión de una humildad epistemológica que sólo permitiría afirmaciones prudenciales y contingentes, en ningún caso verdades con pretensiones universales y objetivas. Para intentar responder a los retos de esta nueva situación es tarea del quehacer teológico conocer adecuadamente dichos planteamientos, distinguir los ámbitos donde sus afirmaciones podrían tener aplicación y percibir con lucidez el alcance de los mismos en la comprensión de la verdad de Dios.

El conocimiento pleno de esta verdad por parte de todos los hombres es designio salvífico divino (cf. 1Tm 2,4) y la teología sirve a la verdad de

2005; J. RATZINGER, Fe, verdad y tolerancia, Salamanca 2005. Próximamente me ocuparé del desafío que representan para el discurso teológico del Dios único las tesis sobre la "distinción mosaica" entre verdad y falsedad, hechas por el egiptólogo J. ASSMAN, Moisés el egipcio, Madrid 2003; ID., La distinción mosaica o el precio del monoteísmo, Madrid 2006.

${ }^{99} \mathrm{Cf}$. la declaración sobre libertad religiosa Dignitatis humanae del concilio Vaticano II. 
Dios en la medida en que hace valer su universalidad. Con los recursos propios del quehacer teológico. Encuentra así en los textos bíblicos la asunción del camino que va de las creaturas al Creador (cf. Sb 13,1-9; Rom $1,18-22$ ), por lo que mantiene la posibilidad de conocer a Dios por la luz natural de la razón ${ }^{100}$ en cuanto expresión de verdad universal. Admitir entonces que en los distintos pueblos se da un cierto conocimiento incluso de Dios Padre y que en los elementos de verdad y santidad presentes en las diversas religiones se refleja un destello de la verdad que ilumina a todos los hombres ${ }^{101}$; descubrir en las tradiciones religiosas de los pueblos "semillas del Verbo latentes en ellas"102; cumplir el mandato universal de Cristo (cf. Hch 1,8) descubriendo en las distintas culturas enraizadas en lo humano modos diversos de acercamiento a la verdad y de apertura del hombre a lo universal y a la transcendencia ${ }^{103}$; admitir con Sto. Tomás de Aquino que "todo lo que es verdadero, sea quien sea el que lo diga, proviene del Espíritu Santo"104; todos estos reconocimientos que orientan hoy el quehacer teológico obedecen a la universalidad de Dios y a la integración del mundo de la creación en el orden de la salvación.

Una teología al servicio de la verdad de Dios necesita hoy día también el diálogo con las llamadas ciencias de la(s) religión(es). Cada una de ellas tiene su propia metodología, distinta de la seguida por el quehacer teológico. A veces pueden surgir puntos de fricción por la delimitación de competencias y por la reivindicación de cientificidad en un campo y en otro. Pero el diálogo ofrece oportunidades de enriquecimiento mutuo y de esclarecimiento metodológico ${ }^{105}$. Muchas de las ciencias de la(s) religión(es), para ser correctas en sus planteamientos, análisis y resultados, no están obligadas metodológicamente a plantearse la pregunta por la ver-

100 Cf., Concilio Vaticano I (1870), DH 3004; cf. GS 21.

101 Cf., los documentos del Vaticano II, NAe 2, LG 16s, AG 9.

102 Cf., AG 11.

$103 \mathrm{Cf}$, Fides et ratio $\mathrm{n}^{\circ} 70$.

104 Cf., STh I-II, q 109, a 1, ad 1; sobre el tema, cf., S.T. BONINO, "Toute vérité, quel que soit celui qui la dit, vient de l'Esprit-Saint". Autour d'une citation de l'Ambrosiaster dans le Corpus thomasien, Rev Thom 106 (2006) 101-147.

105 Cf.: P. GISEL, La théologie face aux sciences religieuses. Différences et interactions, Genève 1999; ID., Tâche et fonction actuelles de la théologie, RThLouv 35 (2004) 289-315; A. DELZANT, Le rapport du théologien aux sciences humaines, Rev Sc Rel 88 (2000) 115-146; J. VAN WIELE, The Place of Phenomenology of Religion in Relation to Theology, "Bijdragen" 61 (2000) 261-284; B. REYMOND, Théologie et sciences de la religion: émergence et actualité d'un problème, RevThPh 133 (2001) 35-55; I.U. DALFERTH, Theologie im Kontext der Religionswissenschaft, ThLZ 126 (2001) 3-20; U. TWORUSCHKA, Selbstverständnis, Methoden und Aufgaben der Religionswissenschaft und ihr Verhältnis zur Theologie, ib. 123138; F. NÜSSEL, Theologie als Kulturwissenschaft?, ThLZ 130 (2005) 1153-1168. 
dad de Dios y de las afirmaciones religiosas. Sin embargo, a la teología no le está permitido practicar semejante abstinencia. Le va en ello su misma razón de ser: la realidad y la verdad de Dios constituyen su propio tema ${ }^{106}$. Y sólo permaneciendo fiel al mismo la teología tendrá algo propio que decir en el concierto de los distintos saberes sobre la(s) religión(es), con los que mantiene un diálogo crítico de escucha y aprendizaje mutuo. Planteando la pregunta por la verdad de Dios hace un servicio no sólo a la fe, sino también al pensamiento, a la cultura y a la sociedad. Servicio no menor porque lo haga desde un discurso comprometido y confesante, más allá de la utilidad funcional y de la neutralidad aséptica.

Otro ámbito de incidencia importante en el contexto postcristiano y postsecular es el establecimiento del sujeto, individual o colectivo, como criterio normativo último. Si se aceptaran los postulados corrientes de que no hay verdad objetiva ni posibilidad alguna de acceso a ella, entonces quedaríamos remitidos al ámbito de las opiniones. Pero, si hemos de aceptar fatalmente este destino, entonces todo se reduce a la ley de lo que las mayorías opinan o lo que los medios de comunicación más influyentes hacen que éstas opinen. En último término, la pregunta por la verdad quedaría reducida a una cuestión estricta de poder o a un asunto de discrecionalidad puramente subjetiva y opcional. Serán entonces los recursos del poder y las leyes del mercado las que decidan, a través de presiones explícitas, indirectas o subliminales, lo que en último término ha de aceptarse como verdadero. O serán las necesidades, los gustos y las preferencias subjetivas del individuo, sus "experiencias" personales las que establezcan el "para mí" como criterio último de discernimiento de la verdad y de actuación correcta ${ }^{107}$.

106 Para su profundización ulterior, cf: W. PANNENBERG, Was ist Wahrheit?, en ID., Grundfragen systematischer Theologie, Göttingen 1979 (202-222) (la pregunta por la verdad es hilo conductor de toda su Systematische Theologie, I-III, Göttingen 1988-1993); E. JÜNGEL, Wertlose Wahrheit. Zur Identität und Relevanz des christlichen Glaubens, München 1990; J. FISCHER, Zum Wahrheitsanspruch der Theologie, ThZ 50 (1994) 93-107 e ID., Pluralismus, Wahrheit und die Krise der Dogmatik, ZThK 91 (1994) 487-539; C. SCHWÖBEL, Die Unverzichtbarkeit der Frage nach dem Wirklichkeitsverständnis des christlichen Glaubens in der Dogmatik, en H. DEUSER (ed.), Systematische Theologie heute, Gütersloh 2004, 102-117. La verdad del cristianismo es una de las preocupaciones fundamentales del actual papa Benedicto XVI, ya en sus épocas anteriores como teólogo y cardenal, cf.: J. RATZINGER, Vérité du Christianisme?, DC n 2217 (2000) 29-35; ID., La verità cattolica, "MicroMega" 2 (2000) 4164; ID., Fe, verdad y cultura. Reflexiones a propósito de la encíclica 'Fides et Ratio', RET 60 (2000) $141-161$

107 Cf., I. U. DALFERTH, "Was Gott ist, bestimme ich!". Theologie im Zeitalter der "Cafeteria-Religion", en ID., Gedeutete Gegenwart: zur Wahrnehmung Gottes in den Erfahrungen der Zeit, Tübingen 1997, 10-35. 
Ahora bien, un discurso teológico que afronte la pregunta por la realidad y por la verdad de Dios revelado en Jesucristo, una verdad "crucificada"108, no puede aceptar como criterios válidos de su quehacer los postulados de que a cada uno su dios, a cada una su diosa y para cada situación vital la divinidad que mejor se acomode. Dios solamente merece este nombre y sólo puede ser aceptado y creído en la fe en la medida en que su realidad decida sobre la verdad o falsedad de nuestros deseos, expectativas, o representaciones. Si Dios es solamente el recurso para ser nosotros mismos, para lograr nuestra propia identidad, para armonizar tensiones o para dominar el desafío de la existencia, bien podría tratarse de un Dios domesticado, descrucificado y evangélicamente irreconocible.

En el contexto contemporáneo, todos estamos marcados por una mentalidad fuertemente utilitarista y funcional. No es de extrañar, por tanto, que las teorías "funcionalistas" de la religión, e.d., las que la equiparan con la función subjetiva, social, antropológica o cultural que desempeñan, gocen de una aceptación amplia y generalizada. $\mathrm{O}$ que esta perspectiva haya entrado en el repertorio de tendencias teológicas, donde todo el centro del interés radica en la utilidad del discurso teológico concreto o en la función que desempeña respecto a la promoción del sujeto que se sirve de determinadas imágenes de Dios. La teología no puede contentarse con ello. Ni proponer caminos donde la comprensión personal de Dios se diluya en una espiritualidad no teísta o se sacrifique la pregunta por la verdad de Dios en aras de la veracidad o autenticidad de la llamada "experiencia" religiosa ${ }^{109}$. La teología ha de servir a la verdad y a la gratuidad de Dios como aquello que puede ser más relevante y significativo precisamente para el hombre de nuestros días. Al permitirle comprender la realidad de un Dios insospechado e intuido en experiencias parciales de gratuidad. $\mathrm{O}$ al abrirle el acceso al Misterio de Dios y a la tradición mística, donde la experiencia del "ya" alimenta el anhelo intenso del "siempre más".

\subsection{El Misterio de Dios}

El carácter insondable del Misterio de Dios Padre, Hijo y Espíritu Santo, en cuanto salvación de los hombres ${ }^{110}$, lleva a una profundización constante de la verdad ${ }^{111}$, que nunca puede darse por concluida. La teolo-

108 Llamativa la coincidencia en el título de dos obras recientes, cf. A. RUSSO, La verità crocifissa. Verità e rivelazione in tempi di pluralismo, Milano 2005; G. RUGGIERI, La verità crocifissa. Il pensiero cristiano di fronte all'alterità, Roma 2007.

109 Cf., en este sentido, las despedidas que propone K.P. JÖRNS, Notwendige Abschiede. Auf dem Weg zu einem glaubwürdigen Christentum, Gütersloh 2005. 
gía queda remitida así en su totalidad al Misterio por antonomasia, que es Dios mismo. Con este reenvío el quehacer teológico se ubica en sus coordenadas propias: la de un discurso creyente, cognoscitivo y sapiencial, llevado a cabo coram Deo, es decir, en remisión constante a Dios mismo como referencia inspiradora, transcendente y crítica de la teología. Y hacer valer esta referencia constituye para ella una exigencia metodológica y un acierto en la situación contemporánea.

Entre los recursos para conseguirlo se halla la conciencia lúcida de que el Dios revelado sigue siendo un Dios escondido (re-velatio). No porque Dios se revele sólo a medias, sino porque el acontecer revelante de la autocomunicación de Dios incluye en la realidad misma de la revelación el hecho de su escondimiento. Del Dios revelado y escondido dan testimonio los grandes teólogos y especialmente las tradiciones místicas. En ambos casos resulta obvio que, con anterioridad a toda búsqueda por parte del ser humano, Dios ha salido ya a su búsqueda y encuentro; él toma la iniciativa que hace de nosotros propiamente los buscados, los interrogados, los interpelados por Dios. Él siempre nos precede. E igualmente nos desborda. Pensar a Dios en cuanto Misterio de precedencia y desbordamiento ${ }^{112}$ hace entonces que el quehacer teológico se lleve a cabo con admiración estremecida y conduzca al silencio adorante. En este sentido, de la teología que es "scientia" y "sapientia", puede decirse con razón que es también "docta ignorantia"113.

\footnotetext{
110 En comparación con el concilio Vaticano I (1870), que hablaba en plural de "decreta" (DH 3004), Dei Verbum 2 habla en singular de "misterio" (cf. Ef 1,9, donde se emplean los términos de "mysterion" - "sacramentum"), mencionando explícitamente su estructura trinitaria.

111 A propósito del artículo de fe sostiene Sto. Tomás de Aquino que "articulus fidei est perceptio divinae veritatis tendens in ipsam", STh II-II, 1,6.

112 Cf: Th. FREYER, Gott als "Geheimnis"? Zu einem theologischen Schlüsselbegriff, ThGl 86 (1996) 325-342; P. REIFENBERG (ed.), Gott, das bleibende Geheimnis, FS W. Seidel, Würzburg 1996; W. KLAGHOFER, Gott als Geheimnis denken? Zu einem (verwaisten) Zentralbegriff der Theologie, MThZ 53 (2002) 337-352; G. KRUCK, Das absolute Geheimnis vor der Wahrheitsfrage. Uber den Sinn und die Bedeutung der Rede von Gott, Regensburg 2002; A. J. KIADI NKAMBU, "Geheimnis Gottes". Gott-mit-uns: Immanuel. Ein Beitrag zum Geheimnisbegriff K. Rahners, E. Jüngels und H.U. von Balthasars, Sant Ottilien 2004; K. LEHMANN, Gott - das bleibende Geheimnis, en G. AUGUSTIN - K. KRÄMER (eds.), Gott denken und bezeugen..., 129-148

113 En relación con la vida eterna hablaba S. Agustín de una "docta ignorantia" (Ep.ad Probam 14, 25 - 15,28; CSEL 44, 68-73), que Benedicto XVI retoma en su encíclica Spe salvi, 11-13. De docta ignorantia es también el título de una influyente obra de Nicolás de Cusa del 1440, ignorancia de la que hace igualmente una defensa razonada, cf. Nicolai de Cusa Opera omnia, iussu et auctoritate Academiae Litterarum Heidelbergensis, vol. II: Apologia doctae ignorantiae, ed. R. KLIBANSKY, Hamburgi 2007; pero, según él, esta ignorancia es camino de acceso a la verdad: "et quanto in hac ignorantia profundius docti fuerimus, tanto magis ipsam accedimus veritatem", De docta ignorantia, I, 3,10.
} 
En la tradición bíblica del AT se halla presente una instancia apofática, que no desaparece con la manifestación definitiva de Dios en la vida, muerte y resurrección de Jesucristo, ya que la presencia del Dios invisible en la concreción de su anonadamiento extremo (cf. Flp 2-5-9) incluye dimensiones de visibilidad paradójica, de escondimiento encubierto, de presencia elusiva, de cercanía sorprendente, de luz inacessible (cf. 1Tm $6,16)^{114}$. Pero será a lo largo de la época patrística cuando se abra paso un apofatismo vinculado a tradiciones místicas e influido por corrientes de pensamiento (neo)platónico. Baste recordar, entre otros, el dinamismo creciente de un "siempre más" expuesto por S. Gregorio de Nisa 115, el camino que transciende afirmaciones y negaciones en Dionisio Areopagita ${ }^{116}$, la incomprensibilidad de Dios en S. Juan Crisóstomo ${ }^{117}$, el conocimiento de la existencia de Dios pero no de su esencia según $\mathrm{S}$. Máximo el Confesor ${ }^{118}$. Por su parte, S. Agustín tenía una conciencia nítida de que Dios es incomprensible ${ }^{119}$, Sto. Tomás de Aquino asume, desplaza y corrige algunos elementos de la teología negativa dionisiana ${ }^{120}, \mathrm{~S}$.

\footnotetext{
114 En referencia al "Señor de los señores" dice $1 T$ m 6,16 "que habita en una luz inaccesible, a quien no ha visto ningún ser humano ni le puede ver".

115 Cf., In Canticum Canticorum, De vita Moysis, De Beatitudinibus, en Gregorii Nysseni Opera, vols. 6, 7/1, 7/2, Leiden 1960, 1964, 1992.

116 Cf. especialmente sus obras De divinis nominibus, ed. B. R. Suchla, Berlin-New York 1990 y De mystica theologia, ed. G. Heil - A. M. Ritter, Berlin-New York 1991. Aunque la interpretación precisa del pensamiento de Dionisio es controvertida entre sus estudiosos (solamente dos vías o momentos teológicos o más bien tres vías), puede decirse que para él Dios está más allá de toda afirmación (tesis, catáfasis) y de toda negación (apófasis, aphairesis), transcendiendo afirmaciones y negaciones en un camino de eminencia que culmina en el silencio. Cf.: Y. DE ANDIA (ed.), Denys l'Aréopagite et sa posteritè en Orient et en Occident, Paris 1996; ID., L' Union à Dieu chez Denys l'Aréopagite, Leiden 1996; J. RICO PAVES, Semejanza a Dios y divinización en el Corpus Dionysiacum, Toledo 2001; S. COAKLEY - C. M. STANG (eds.), Re-thinking Dionisius the Areopagite, Modern Theology $24 / 4$ (2008) 535-754.

117 Cf.. De incomprehensibile Deo, SC 28bis, Paris 1970.

118 Cf., Maximi Confessoris Ambigua ad Iohannem iuxta Iohannis Scotti Eriugenae latinam intepretationem, ed. E. JEAUNEAU, CC Series Graeca 18, Turnhout-Leuven 1988 (cf. Ambigua 15, 16,17, donde comenta algunos pasos de Gregorio Nazianzeno, Oratio 28, 5-6, SC 250 , Paris 1978,110 s, en los que atribuye al hombre la percepción de que Dios es, pero no de qué es, es decir, de su existencia pero no de su substancia y su esencia). Ambigua 15, 16, 17, donde comenta algunos pasos de Gregorio Nazianzeno, Oratio 28, 5-6, SC 250, Paris 1978, 110 s, en los que atribuye al hombre la percepción de que Dios es, pero no de qué es, es decir, de su existencia pero no de su substancia y su esencia).

119 "De deo loquimur, quid mirum si non comprehendis? Si enim comprehendis, non est deus", S. AGUSTÍN, Sermo 117,5; "si quasi comprehendere potuisti, cogitatione tua te decepisti", PL 38, 360, 663; cf. también supra n. 139.

120 Sin olvidar las precisiones ulteriores que exige determinar su relación con Dionisio, puede decirse que Sto. Tomás le sobrepasa en el desarrollo de la vía eminencial. Para Sto. Tomás la teología apofática viene pedida y posibilitada por la catafática, según el principio de
} 
Buenaventura habla de la transcendencia del Dios presente en la creación y reinvindica el valor del exceso, de la negación y del silencio'21.

Especial importancia alcanza el apofatismo en autores místicos, cuyas obras llenas de expresiones paradójicas combinan simultáneamente experiencia espiritual y reflexión teológica ${ }^{122}$. La teología protestante se mostró en sus comienzos muy crítica frente a un apofatismo marcado por el pensamiento filosófico ${ }^{123}$; pero dió gran relieve a la idea del Dios escondido y a la peculiaridad de la cruz de Cristo como momento decisivo de la revelación y del conocimiento de Dios ${ }^{124}$. La idea del Dios escondido y la necesidad de una teología negativa como correctivo de la afirmativa tienen un valedor eminente en Nicolás de Cusa125. Por su parte la teología ortodoxa, tan arraigada en la teología patrística, ha mantenido una tradición apofática que junto con su impregnación doxológica constituyen un

que "omnis negatio fundatur in aliqua affirmatione" (cf. I Sent. d 35 q1 a1 ad2; STh, I q33 a4 ad3, I-II q71 a6 q72 a6, q75 a1; II-II q79 a3 ad 1), principio también recordado por S. Alberto Magno, In Diony., c. $1, \mathrm{n}^{\circ} 50$, ob. 3. Ello no obsta a la asunción de un apofatismo dionisiano, que niega a Dios el "hoc ipsum esse" tal como se halla en las creaturas y que habla de "quadam tenebra ignorantiae" y de una cierta "caligo" en la que Dios habita (cf. Scriptum super Libr. Sent. I, d8 q1 a1 ob. 4 ad 4). La misma idea del Dios desconocido encuentra acogida en Sto. Tomás: "Dyonisius dicit quod Deo quasi ignoto coniungimur; quod quidem contingit dum de Deo quid non sit cognoscimus, quid vero sit penitus manet ignotum. Unde et, ad huius sublimissimae cognitionis ignorantiam demonstrandam, de Moyse dicitur quod accesit ad caliginem in qua erat Deus", ScG III, c. 490. Cf., T. D. HUMBRECHT, Théologie négative et noms divins chez saint Thomas d'Aquin, Paris 2005.

$121 \mathrm{~S}$. Buenaventura habla, por ejemplo, de una acción creadora y sustendora de Dios en todo, pero sin perder por ello su transcendencia: "ideo est intra omnia, non inclusum; extra omnia, non exclusum; supra omnia, non elatum; infra omnia, non prostratum", Itinerarium, V, 8. Cuando trata la cuestión de los nombres divinos habla de una triple nominación de Dios "per causalitatem, per ablationem et per excellentiam", I Sent. $d 22$, au. q2, resp. (I 393b). En el epílogo de las cuestiones dedicadas al conocimiento de Cristo, asume la herencia de Dionisio citando Ap 2,17 (V, 43a-b).

122 Baste mencionar aquí algunos nombres como el maestro Eckhart, S. Juan de la Cruz o Angelus Silesius, cuya integración de experiencia espiritual, reflexión teológica y lenguaje simbólico no constituyen excepciones en la historia del cristianismo, sino más bien momentos destacados.

123 Cf., M. LUTERO, De captivitate Babylonis, WA, VI, 562, 3ss. $\mathrm{V}, 108$

124 "Sed Christum nosse, est Crucem nosse et deum sub carne crucifixa intelligere", WA

125 Una obra de N. de Cusa lleva por título De deo abscondito, cf. Opera omnia, vol. IV, Opuscula I, Hamburgi 1959; en De possest afirma: "Est enim deus occultus et absconditus ab oculis omnium sapientum, sed revelat se parvulis seu humilibus, quibus dat gratiam", Opera omnia, vol. XI/2,36s; a propósito de las afirmaciones y las negaciones teológicas sostiene: "Et ita theologia negationis adeo necessaria est quoad aliam affirmationis, ut sine illa Deus non coleretur ut Deus infinitus, sed potius ut creatura; et talis cultura idolatria est, quae hoc imagini tribuit, quod tantum convenit veritati... negationes sunt verae et affirmationes insufficientes in theologicis", Opera omnia, vol. I, c. 26. Cf., W. BEIERWALTES, Cusanus. Reflexión metafisica y espiritualidad, Pamplona 2005; igualmene los arts. incluídos en el $\mathrm{n}^{\circ}$ de ThQ 181/2 (2001) 81-155 dedicados al pensamiento de N. de Cusa. 
caudal de enriquecimiento para el quehacer teológico en perspectiva ecuménica. En resumen, sin ignorar las diversas variaciones ni querer reducirlas forzadamente a un común denominador, la instancia apofática puede retenerse como un patrimonio común de la tradición cristiana, presente también en numerosos documentos del magisterio eclesial ${ }^{126}$, que necesita ser repensado en las circunstancias actuales.

En nuestra situación postcristiana y postsecular el recurso al "apofatismo" o a la "teología negativa" acontece en contextos muy diversos y encierra una plurivalencia de significados que va más allá del horizonte bíblico-teológico como presupuesto ${ }^{127}$. En ocasiones estamos ante una clave hermeneútica para interpretar la situación presente marcada por la indiferencia, el olvido y la ausencia cultural de Dios (el vivir de muchas personas etsi Deus non daretur). Un especial relieve alcanza cuando recoge los interrogantes del mal, de la injusticia y del sufrimiento de los inocentes. Situadas en este transfondo, algunas corrientes de la filosofía contemporánea emplean las expresiones para sostener que en relación con Dios no es posible afirmación ni negación alguna; quedaría como propuesta sólo el silencio completo y la a-teología radical, incluso manteniendo resquicios de apertura hacia un interrogante último inaccesible e innombrable. En otras ocasiones la teología negativa y su vinculación con tradiciones místicas se proponen como oportunidad nueva para un encuentro inédito entre las distintas confesiones religiosas no ya en el habla sobre Dios, sino en el silencio ante su Misterio.

ita theologia negationis adeo necessaria est quoad aliam affirmationis, ut sine illa Deus non coleretur ut Deus infinitus, sed potius ut creatura; et talis cultura idolatria est, quae hoc imagini tribuit, quod tantum convenit veritati... negationes sunt verae et affirmationes insufficientes in theologicis“, Opera omnia, vol. I, c. 26. Cf., W. BEIERWALTES, Cusanus. Reflexión metafísica y espiritualidad, Pamplona 2005; igualmene los arts. incluídos en el $n^{\circ}$ de ThQ 181/2 (2001) 81-155 dedicados al pensamiento de N. de Cusa.

126 En relación con la fe trinitaria afirma el concilio IV de Letrán (1215) que „inter creatorem et creaturam non potest tanta similitudo notari, quin inter eos maior sit dissimilitudo notanda“, DH 806; en la ed. de DS 806 se habla sólo de "similitudo“ sin el adjetivo „tanta“. Cf. también DH 3016, DH 3005 y CCE (1997) n 43.

127 Cf.: L. BOEVE, Postmodernism and Negative Theologie, "Bijdragen" 58 (1997) $407-$ 425; Voies Negatives I RevScRel $67 / 4$ (1993 y II, RevScRel $72 / 4$ (1998); D. CARABINE, The Unknow God. Negative Theologie in the Platonic Tradition, Leuven 1995; W. OELMÜLLER, Negative Theologie heute, München 1999; T. A. CARLSON, Indiscretion. Finitude and the Naming of God, Chicago 1999; I.N. BULHOF - L. TEN KATE (eds.), Flight of the Gods. Philosophical Perspectives on Negative Theology. New York 2000; M. STRIET, Offenbares Geheimnis. Zur Kritik der negativen Theologie, Regensburg 2003; O. PUJOL - A. VEGA (eds.), Las palabras del silencio. El lenguaje de la ausencia en las distintas tradiciones místicas, Madrid 2006; J.D. CAPUTO - M. J. SCANLON (eds.), Transcendance and Beyond. A Postmodern Inquiry, Bloomington USA 2007; A. HALBMAYR - G.M. HOFF (ed.), Negative Theologie heute? Zum aktuellen Stellenwert einer umstrittenen Tradition, Freiburg i.B. 2008. 
A su vez, en el ámbito intracristiano, las expresiones encierran con frecuencia el deseo de purificar el lenguaje religioso y el discurso teológico para evitar absolutizaciones linguiísticas, idolatrizaciones conceptuales o abusos llevados a cabo en nombre de Dios; en otros casos, los acentos recaen sobre la necesidad de recuperar al Dios de los místicos ${ }^{128}$ frente al Dios de los teólogos y de los moralistas o sobre el redescubrimiento de una relación olvidada entre filosofía, oración y teología. En fin de cuentas, los distintos recursos al apofatismo y a la teología negativa en la situación presente piden del quehacer teológico un esclarecimiento como servicio a la verdad de Dios ${ }^{129}$.

Referencia obligada para la teología cristiana será, ante todo, el primado de la revelación y la centralidad del acontecimiento Jesucristo; aquí Dios ha hablado definitivamente por medio de su Palabra, hecha carne real e historia concreta. Por ello es posible una teología afirmativa como resultado de la escucha obediente hacia la Palabra revelada y encarnada, que siempre nos precede. Sin esta centralidad de Jesucristo no hay apofatismo cristiano válido ${ }^{130}$. El Misterio de Dios revelado en Jesucristo y en el Espíritu Santo es el de un Dios trinitario, que es misterio de ék-stasis (descentramiento y salida de sí mismo), de kénosis (anonadamiento radical en la cruz como meta de la encarnación) y de exceso (semper maior en su ser y actuar respecto a todas las semejanzas posibles). No es sin más el misterio del silencio ensalzado en algunas tradiciones filosóficas ${ }^{131}$, ajenas a lo sensible o material y cerradas a la idea de encarnación de Dios; en cuanto su Palabra encarnada, Jesucristo rompe el "silencio de Dios"132. Ni es el misterio de un Dios apersonal, propio de algunas tradiciones religiosas orientales.

128 Cf., A. BERNARD, Le Dieu des mystiques, 2 vols., Paris 1994, 1998; M.A. MCINTOSH, Mystical Theology, Oxford 1998; J. MARTIN VELASCO, La experiencia mística. Estudio interdisciplinar, Madrid 2004.

129 Cf. H. U. VON BALTHASAR, ¿Teología negativa?, en ID., Teo-Lógica, 2: La verdad de Dios, Madrid 1997, 87-121.

${ }^{130} \mathrm{El}$ mismo N. de Cusa dice lo siguiente: "Jesus igitur est apparitio absconditi Dei seu revelatio sive ostensio", Sermo CCLX; "Est enim unus ostensor, magister scilicet Iesus Christus. Ille in se ostendit patrem, ut qui eum meruerit videre qui est filius, videat et patrem", De possest, Opera omnia, vol XI/2, 36 .

131 Cf., PROCLUS, Hymnes et prières, trad. H. D. Saffrey, Paris 1994, 78s, himno al silencio atribuído también por otros autores a G. Nazianzeno o al mismo Dionisio Areopagita.

$132 \mathrm{~S}$. Ignacio de Antioquía habla en varias ocasiones del silencio de Dios; cf. Ad Eph. XV, 1-2 y sobre todo Ad Magn. VIII, 2, donde, inspirándose en Rm 16,25 ("misterio mantenido en silencio durante siglos"), dice que el Hijo Jesucristo es "el Logos salido del silencio". Se sirve así de temas presentes en los sistemas gnósticos para expresar el misterio manifestado en Jesucristo: en cuanto salido del Padre (Ad Magn. VI,1; VII,2) y salido del silencio en que se hallaba junto a él (Ad Eph. XV,1) es la boca a través de la cual Dios ha hablado en verdad ( $A d$ Rom VIII,2). 
Dentro de un apofatismo parcialmente compartido, presente también en religiones monoteístas como el judaísmo o el islam, cuando la teología cristiana habla de vía negativa y de enmudecimiento se refiere al Misterio trinitario de Dios en cuanto misterio de salvación. Y ante la elocuencia suprema de la Palabra divina hecha carne y anonada hasta el extremo, cualquier palabra teológica resulta deficiente: "deficiunt voces, crescente verbo" 133 . La vía negativa no se disuelve así en pura negatividad, sino que se transciende en supereminencia y conduce al silencio de la adoración ${ }^{134}$.

Lo cual no significa el final de la teología cristiana. La contraposición entre infinitud de Dios y finitud del ser humano o la limitación del ser creado para comprender mediante su capacidad cognoscitiva una realidad que le transciende y desborda son tesis filosóficas, cuya apropiación ha resultado benéfica para pensar al Dios de Jesucristo en el quehacer teológico ${ }^{135}$. Las palabras y los conceptos quedan relativizados por el Misterio absoluto de Dios ${ }^{136}$, al que continuamente remiten. Así, la simultaneidad de semejanza y desemejanza, afirmación y transcendencia impiden convertir el camino de la analogía, justificado como proceder, en un recurso que termine aprisionando a Dios dentro de los conceptos. La desemejanza perceptible partiendo de la creación alcanza en el acontecimiento de la cruz su expresión máxima de interrupción y ruptura. Los mismos enunciados dogmáticos son ajenos a cualquier pretensión de encerrar a Dios dentro de sus formulaciones. Aquí tiene validez la distinción entre forma enunciativa y contenido veritativo del depositum fidei ${ }^{137}$, lo que no dispensa a la teolo-

133 "Quia deficiunt voces, crescente verbo: quia Illum oportet crescere, me autem minui. Verbum quidem per se ipsum nec crescit, nec deficit in se. In nobis autem crescere dicitur, cum proficiendo in illum crescimus... Minuitur ergo ministerium vocis, cum fit mentis profectus ad Verbum", S. AGUSTíN, Sermo 288, 5; cf., también De Trinitate, XV.

134 "Deus honoratur silentio, non quod de ipso nihil dicamus vel inquiramus, sed quia intelligimus nos ab eius comprehensione defecisse", TOMÁs DE AQUINO, In Boet. de Trin., q2 a1 ad6, en sintonía con la tradición dionisiana. En esta misma línea, cf. N. DE CUSA: "Eo modo, cum de ipso nihil proprie dici aut affirmari possit, quod non excedat, in silentio ipsum admiramur et contemplamur et colimus", Cribatio Alkorani, II, c.1, Opera omnia, VIII, 74. Cf. también, S. GREGORIO NAZIANZENO, Carmen 29, PG 37, 508.

135 "Scimus incomprehensibile... non aliter quam incomprehensibiliter attingimus", $\mathrm{N}$. de Cusa, De docta ignorantia, I,3,10; I,4,11. La incomprensibilidad de Dios queda recogida en la profesión de fe del IV concilio de Letrán (1215) (cf. DH 800) y en el concilio Vaticano I (1870) (cf. DH 3001).

136 Entre los teólogos contemporáneos merece destacarse la aportación de Karl Rahner al repensamiento de Dios como Misterio. Con ocasión del 25 aniversario de su muerte, en el próximo $\mathrm{n}^{\circ}$ de "Burgense" aparecerá un trabajo mío dedicado a este tema.

137 En su discurso de apertura del concilio Vaticano II Gaudet mater ecclesia, Juan XXIII hizo una distinción que iba a marcar el desarrollo de la teología conciliar y postconciliar: "Est enim aliud ipsum depositum Fidei, seu veritates, quae veneranda doctrina nostra 
gía de las cuestiones hermeneúticas ni de la pregunta por la continuidad diacrónica y sincrónica de la fe y por un lenguaje comúnmente compartido. Las aserciones dogmáticas, en cualquier caso, nos reenvían continuamente en sus diversas formulaciones al Dios creído y conocido en la fe138.

Ya ahora, en la existencia terrena y a la espera de su plenitud definitiva, el conocimiento y la experiencia de Dios están inhabitados por un dinamismo creciente, que hace de cada momento vivido un estímulo continuo de desarrollo e intensidad ulterior. El deseo espiritual de "siempre más" se integra así en la esperanza escatológica del "todavía no" y halla su correspondencia en la realidad de un Dios "siempre mayor". Articular con acierto esta triple dimensión contribuirá a que la teología dé respuesta a demandas ampliamente sentidas hoy día. La de teólogos deseosos de que la instancia apofática enriquezca el discurso creyente ubicándolo en sus coordenadas justas. Y la de personas para quienes "teología negativa" es sinónimo de desconocimiento, inexperiencia y ausencia de Dios, tanto en el plano personal como cultural. El discernimiento del quehacer teológico estará abierto entonces a las posibilidades de empatía y encuentro, no obstante la aparente lejanía entre apofatismo creyente y enmudecimiento agnóstico. Y aquí habremos de escuchar sobre todo a los expertos de la experiencia de Dios en caminos marcados por la luz y por la obscuridad.

\section{Conclusión}

A lo largo de mi intervención he intentado presentar algunos elementos de la relevancia que encierra hacer valer a Dios como "sujeto" de la teología. Elementos que inciden en la confrontación con los desafíos actuales de una cultura postcristiana y postsecular.

\footnotetext{
continetur, aliud modus, quo eaedem enuntiantur, eodem tamen sensu eademque sententia"; cf. en esta misma línea GS 62 (donde se citan las palabras del papa), UR 4 (donde en perspectiva ecuménica se reconoce una debida libertad "immo et in theologica veritatis revelatae elaboratione") y UR 17 (donde a propósito de las tradiciones teológicas de oriente y occidente se reconoce que "tunc variae illae theologicae formulae non raro potius inter se compleri dicendae sint quam opponi").

138 En relación con la fe asegura Sto. Tomás de Aquino que ,actus credendi non terminatur ad enuntiabilem, sed ad rem" (STh II-II, 1,2) y el último CCE (1997) hace suya la distinción entre "credere in Deum Patrem et Filium et Spiritum Sanctum" y "credere Ecclesiam": "In Symbolo Apostolico profitemur nos credere sanctam Ecclesiam (« Credo [...] Ecclesiam ») et non in Ecclesiam, ne Deum Eiusque confundamus opera et ut clare bonitati attribuamus Dei omnia dona quae Ipse in Sua posuit Ecclesia" ( $\left.n^{\circ} 750\right)$, haciendo suyo lo que ya indicaba el Cathecismus Romanus 1, 10, 22.
} 
Estos retos y desafíos para la fe en Dios están ahí, no es posible obviarlos y han de ser afrontados. Pero en cuanto teólogos creyentes no podemos conformarnos con el elenco reiterativo y creciente de los mismos, es necesario también ofrecer respuestas positivas por parte de la teología. Por eso estoy a favor de invertir los planteamientos: del repertorio de desafíos para el cristianismo a la propuesta del cristianismo como desafío; e.d., tomar los retos que ha de afrontar la fe cristiana en Dios no como polo de referencia obsesivo, sino como estímulo para (re)centrarse en los núcleos más decisivos de esta fe en cuanto propuesta teórico-práctica capaz de interpelar, de mantener una esperanza que no claudica ni ante la muerte y de atraer por la fuerza del testimonio vivido y de los contenidos positivos que propone. Con otras palabras: pensar teológicamente desde dentro hacia afuera, desde el interior más nuclear de la fe en dirección a horizontes más amplios y dilatados.

Algo así es posible desde la primacía, la verdad y el Misterio de Dios. Con ello no solamente se abre el camino a la doxología adorante como dimensión propia de la racionalidad creyente, que es el quehacer teológico. Se ofrece también al hombre moderno y contemporáneo una ayuda para ampliar los horizontes del conocer. Con frecuencia, el comprender se equipara a una forma de dominar. De ahí que la aceptación de Aquel que siempre nos precede con su realidad y su verdad y que es incomprensible en su alteridad divina, se trạnsforme en escuela de aprendizaje para un tipo de comprender marcado no por el ansia de dominio, sino por la aceptación del otro en su alteridad incomprensible. Hacer valer a Dios como "sujeto" de la teología comporta, por ello, consecuencias también antropológicas. El sujeto que conoce y que no "dispone" de su propio fundamento (Dios) permanecerá siempre abierto frente a todo otro que es realmente distinto. Y si la teología, en la diversidad de sus propuestas y de sus métodos, contribuye a (re)descubrir esta realidad en el contexto de una cultura que en parte es postcristiana y postsecular, no habrá sido el suyo un trabajo en vano. 